\title{
LAS POTESTADES SANCIONADORA Y ¿DISCIPLINARIA? DE LA ADMINISTRACIÓN ELECTORAL
}

\author{
FABIO PASCUA MATEO' \\ Universidad Complutense de Madrid \\ fapascua@ucm.es
}

Cómo citar/Citation

Pascua Mateo, F. (2017).

Las potestades sancionadora y ¿̇disciplinaria? de la Administración electoral. Revista de Administración Pública, 202, 393-435.

doi: https://doi.org/10.18042/cepc/rap.202.14

\section{Resumen}

El presente estudio aborda los aspectos fundamentales de la potestad punitiva de la Administración electoral. Desde la perspectiva de las sanciones administrativas, expone el régimen general a la luz de las disposiciones contenidas en la LOREG y en las nuevas leyes 39 y 40/2015, con especial atención a problemas como la deficiente tipificación de infracciones y el ineficaz sistema de sanciones, todo ello atendiendo a la doctrina emanada de las resoluciones de la Junta Electoral Central. A continuación, se detalla la regulación de las dos conductas específicamente tipificadas como infracciones, a saber, la vulneración del régimen de publicación de encuestas y la superación del límite de gastos electorales. El trabajo concluye con un repaso a la potestad disciplinaria de las Juntas, cuyos principales contornos se perfilan, y que se deslinda de la que a su vez puedan mantener las Administraciones de pertenencia de quienes intervienen oficialmente en el proceso electoral.

\section{Palabras clave}

Administración electoral; sanciones administrativas; potestad disciplinaria.

1 Profesor titular de universidad. 


\begin{abstract}
This study addresses the fundamental aspects of the punitive power of the electoral administration. From the perspective of administrative penalties, it exposes the general scheme in the light of the provisions of the LOREG and the new laws 39 and 40/2015, construed according to the resolutions of the Central Electoral Board, with special attention to problems such as the poor definition of offences and the ineffective system of sanctions. Besides, the regulation of the two behaviors specifically classified as infractions, namely, the breach of the polls publication regime and overcoming the limit of election expenses, is detailed. The paper concludes with a review of the disciplinary authority of the Boards, whose main outlines are drawn, and that is distinguished from the one that the Administrations of belonging of those officially involved in the electoral process keeps at the same time.
\end{abstract}

\title{
Keywords
}

Electoral administration; administrative sanctions; disciplinary power. 


\section{SUMARIO}

I. EVOLUCIÓN HISTÓRICA. II. NORMATIVA APLICABLE. III. ÓRGANOS COMPETENTES. IV. LA DEFECTUOSA TIPIFICACIÓN DE LAS CONDUCTAS INFRACTORAS. V. REGULACIÓN DE LAS SANCIONES: 1. Un sistema de sanciones ineficaz. 2. La graduación de las sanciones. VI. PRESCRIPCIÓN DE INFRACCIONES Y SANCIONES. VII. EL PROCEDIMIENTO SANCIONADOR: 1. Iniciación. 2. Tramitación. 3. Resolución. VIII. RECURSOS. IX. CONSIDERACIONES SOBRE LAS DOS INFRACCIONES CON TIPIFICACIÓN ESPECÍFICA: 1. La vulneración del régimen sobre encuestas electorales. 2. La superación de la cuantía máxima autorizada de gastos electorales. X. LA POTESTAD DISCIPLINARIA.

\section{EVOLUCIÓN HISTÓRICA}

En 1876 escribía D. Manuel Colmeiro que «para que la elección exprese la voluntad general es condición necesaria que el Gobierno proteja el libre ejercicio de un derecho que ó nada vale, ó reviste el carácter de un acto de soberanía nacional de que participa cada ciudadano [...] Toda influencia ilegítima, y mucho más, toda fuerza capaz de extraviar ú oprimir la conciencia del elector, deben ser reprimidas, y sus autores severamente castigados» ${ }^{2}$. Casi ciento cincuenta años después, a pesar de situarse en contextos bien distintos, el art. 153 de la LOREG reconoce una potestad sancionadora a los órganos de la Administración electoral ${ }^{3}$, que constituye una más de las respuestas previstas por el ordenamiento para asegurar el adecuado desarrollo de las elecciones, previniendo y en su caso reprimiendo los comportamientos ilegales que atenten

2 M. Colmeiro (1876), Derecho Administrativo Español, tomo primero, Madrid: Imprenta y librería de Eduardo Martínez (pág. 555). No obstante, con buen sentido, recuerda este autor a continuación que «algo pueden las buenas leyes para corregir estos abusos, pero pueden más las buenas costumbres».

3 Acerca de la naturaleza jurídica, órganos que la integran, funcionamiento y competencias de la Administración electoral, véase F. Pascua Mateo (2007), La Administración electoral, Madrid: INAP. 
contra su pureza ${ }^{4}$. Se sigue así una tradición que se remonta al nacimiento del sistema de Juntas electorales en 1890, pues anteriormente las leyes electorales regulaban un sistema nítidamente penal, que distinguía solo entre delitos y faltas ${ }^{5}$. En efecto, la ley que reforma la electoral para diputados a Cortes, de 26 de junio de 1890, reconoce la potestad disciplinaria de la Junta Central del Censo y de su presidente para imponer multas de hasta 1000 pesetas a todas las personas que oficialmente interviniesen en las operaciones electorales (art. 18.5), así como para alzar las sanciones impuestas por las Juntas inferiores y los alcaldes. A dicha potestad se le une, aunque no se mencione expresamente, la de sancionar con carácter general las infracciones de la normativa electoral cometida por otros sujetos. La tipificación de las infracciones se lleva a cabo por los arts. 98 y 99, que integran el capítulo II, «De las infracciones», del título VI, «De la sanción penal». El primero regula los tipos disciplinarios, pues afecta a quienes, interviniendo oficialmente en las operaciones electorales, infrinjan las obligaciones que la propia ley o sus disposiciones de desarrollo les impongan. El segundo se adentra, en cambio, en la potestad sancionadora estricta y, en consecuencia, enumera una serie de conductas más específicas, susceptibles de ser cometidas por cualquier sujeto, tales como la alteración del orden en actos electorales cuando no constituya delito, la entrada indebida en el colegio electoral o su permanencia en él frente a la intimación del presidente de la mesa, o el hacerlo portando armas. No obstante aparaecen también infracciones típicamente disciplinarias, como la inasistencia a las sesiones de las Juntas por parte de sus vocales, o la omisión de dar trámite a los documentos electorales por parte de los funcionarios competentes. El procedimiento se regula en el

4 La importancia del elemento represivo para garantizar la limpieza de los comicios es incluso más antigua, pues está ya presente en la Roma clásica, como lo atestigua una obrita de Quinto, el hermano menor de Cicerón, Commentariolum Petitionis, en la que el autor anima a velar "por la dignidad del proceso", entre otros medios con la amenaza a los competidores con un juicio para refrenar el tráfico de votos. Véase Q. Tulio Cicerón (2003), Breve manual de campaña electoral, Madrid: Alianza Editorial (pág. 86).

5 Es cierto que la Ley de 1878, en el capítulo III de su título VI, «De la sanción penal», habla de infracciones de la ley electoral, pero estas mantenían la naturaleza penal, como una modalidad diversa de conductas que se sumaban a las falsedades y las coacciones, reguladas en los capítulos I y II, respectivamente. Acerca de la legislación electoral decimonónica, puede consultarse A. Fernández Domínguez (1992), Leyes electorales españolas de diputados a Cortes en el siglo XIX, Madrid: Civitas. Asimismo, sobre la evolución histórica de la Administración electoral, Pascua Mateo (2007: 19) y P. Martínez Ruano (2008), Antecedentes históricos de la Administración electoral, Almería: Editorial Universidad de Almería. 
art. 107, que exige resolución motivada, recurrible en alzada en el plazo de dos días desde su notificación. El acuerdo que resolvía dicha alzada debía limitarse a confirmarla o revocarla, salvo que lo dictara la Junta Central, la cual podía además agravar o disminuir la sanción impuesta. Estas prescripciones se reprodujeron sin alteraciones relevantes en los arts. 33 y siguientes del Real Decreto de 26 de noviembre de 1897, por el que se aprueba la Ley de Adaptación a la Isla de Cuba y de Puerto Rico de la Ley Electoral de 25 de junio de $1890^{6}$.

Por su parte, la Ley electoral de 10 de agosto de 1907 reproduce en buena medida el régimen anterior, si bien introduce algunas variantes. Así, su art. 15.7 establecía que era competencia de la Junta Central del Censo: «Ejercer jurisdicción disciplinaria sobre todas las personas que intervengan con carácter oficial en las operaciones de formación, rectificación, conservación ó compulsa del censo, imponiendo multas hasta la cantidad de 1000 pesetas», a la que el apartado 8 del mismo artículo añadía la de "Corregir las infracciones concernientes á formación, rectificación, conservación ó compulsa del censo que no estén reservadas a los Tribunales; imponer las multas á que den lugar las faltas de envío oportuno de cualquier documento ó comunicación, é imponer, alzar y agravar multas dentro del límite legal de sus atribuciones». El art. 16 reconocía análogas atribuciones a las Juntas provinciales y municipales, si bien la cuantía máxima de las sanciones no podía superar, respectivamente, las 500 y 100 pesetas. La tipificación de las conductas infractoras se lleva a los arts. 75 y 76, respectivamente para faltas disciplinarias e infracciones administrativas, que conforman el capítulo II, "De las infracciones», del título VIII de la Ley, dedicado a la «Sanción penal». No varían los tipos previstos en la Ley de 1890, salvo la infracción prevista para la inasistencia de los miembros de las Juntas que se regula, no obstante, en el art. 17. Quizá la única excepción reseñable sea la tipificación de las sanciones correspondientes a la omisión del deber de emisión del voto, que se configuraba como obligatorio. El procedimiento se regulaba en su art. 86, en los mismos términos que en la norma precedente.

En tiempos ya más recientes, y de forma muy similar al actual art. 153 LOREG, el art. 93 del Real Decreto Ley 20/1977, de 18 de marzo, disponía que: «Toda infracción de las normas obligatorias establecidas en la presente

6 Por ley de 17 de mayo de 1898 se declaró «exento al actual Gobierno de la responsabilidad constitucional en que ha incurrido al publicar, sin acuerdo legislativo» el Real Decreto que concede el régimen autonómico a ambas islas, técnica conocida como ley de indemnidad que, siguiendo el modelo inglés, anticipa el mecanismo de los decretos leyes. Aunque no lo menciona expresamente, dado que su fecha es idéntica y que la ley regula, entre otras, las cuestiones electorales relativas a los órganos representativos autonómicos, se pudo entender que también el Real Decreto citado en el cuerpo del texto quedaba cubierto por dicha exención. 
norma o en las disposiciones que se dicten para su ejecución, que no constituyan delito, serán sancionadas por las Juntas electorales con multa de cinco mil a cincuenta mil pesetas, si se trata de autoridades o funcionarios, y de mil a veinticinco mil pesetas, si se realizan por particulares». Este precepto se completa con la atribución de las competencias de la Junta Electoral Central en el art. 14.7, conforme al cual le corresponde: «Corregir las infracciones que se produzcan, siempre que no estén reservadas a los Tribunales, o imponer las multas que estime pertinentes, hasta la cantidad de cincuenta mil pesetas, de acuerdo con lo dispuesto en el título VIII de estas normas» ${ }^{7}$. El art. 15.2 extiende esta potestad a las Juntas inferiores, pero «limitada a la cuantía máxima de veinticinco mil pesetas para las Juntas Provinciales y de diez mil para las de Zona». En materia de procedimiento regía el art. 76.5.c), según el cual: «En los expedientes sancionadores serán de aplicación, como mínimo, los requisitos previstos en el título VI, capítulo II de la Ley de Procedimiento Administrativo. En ningún caso podrán las Juntas electorales, al resolver los recursos que ante ellas se formulen, agravar las sanciones impuestas por las resoluciones impugnadas».

\section{NORMATIVA APLICABLE}

En el derecho vigente, la potestad sancionadora de la Administración electoral se regula en los apartados 1 a 3 del art. 19 y en el art. 153 LOREG. A estas previsiones deben añadirse las atribuciones análogas reguladas en las respectivas leyes electorales autonómicas para las Juntas de este ámbito. A grandes rasgos, el art. 19 establece que las Juntas Electorales son titulares de una potestad sancionadora en su doble perspectiva interna —en forma de facultades disciplinarias sobre las personas que intervengan con carácter oficial en las operaciones electorales - y externa, respecto de las infracciones que se produzcan en el proceso electoral y que no estén tipificadas como delito. Además, establecen un límite para la cuantía de las multas que pueden imponer las distintas Juntas territoriales, que se cifra en mil doscientos euros para las provinciales y seiscientos para las de $z \mathrm{zona}^{8}$, de modo que la Central puede apurar el máximo legalmente previsto. En el caso de las Juntas de comunidad autónoma, aunque existen algunas diferencias, la multa máxima suele fijarse

7 El apartado 6 de este precepto regula asimismo, como se verá, la potestad disciplinaria de dicho órgano.

8 Las cuantías citadas han sido fijadas por el art. 5 de la Ley Orgánica 2/2011, de 28 de enero, que sustituye las antes vigentes de cien mil y cincuenta mil pesetas. 
en ciento cincuenta mil pesetas o su equivalente en euros, $901,52^{9}$, si bien hay casos en que se llega a las doscientas mil e incluso a las cuatrocientas o quinientas mil pesetas si se trata de infracción de la normativa de encuestas electorales ${ }^{10}$.

La escueta regulación de la LOREG se completa con el art. 153, cuyo apartado 1 determina que toda infracción de las normas obligatorias establecidas en esta Ley que no constituya delito será sancionada por la Junta Electoral competente, a la par que se fijan las cuantías máximas de las multas, con la excepción de las producidas por infracción del régimen de encuestas electorales. Tras la Ley Orgánica 1/2003 se añadió un tercer apartado que impone a las infracciones de las previsiones sobre subvenciones por gastos electorales la aplicación de la normativa contenida en la Ley General Presupuestaria, que fue derogado por la Ley Orgánica 2/2011, de 28 de enero. No obstante ha vuelto a aparecer, con alguna modificación relevante que se verá en su momento, por mor de la Ley Orgánica 3/2015, de 30 de marzo.

Las leyes autonómicas, por su parte, no suelen contener una disposición análoga al art. 153 LOREG, más allá de la definición citada de la potestad sancionadora, en su caso, de la Junta Electoral respectiva. Como excepciones cabe mencionar, sin embargo, el art. 132 de la Ley 5/1990 electoral del Parlamento vasco y el art. 46 de la Ley 1/1987, electoral valenciana, redactadas en términos similares a los expuestos.

Más allá de la legislación electoral, ha de destacarse que la entrada en vigor de la Ley $39 / 2015^{11}$ ha venido a alterar el panorama de fuentes que regula el procedimiento sancionador de la Administración electoral. Hasta este momento se había considerado durante mucho tiempo que no existía una regulación reglamentaria específica, ya que la falta de una Instrucción a tal efecto de la JEC no podía rellenarse, según doctrina reiterada de ésta ${ }^{12}$ confirmada por

9 Así, art. 13.e) de la Ley electoral de Andalucía; art. 10.d) de la Ley electoral de Aragón; art. 8.2.d) de la Ley electoral del Principado de Asturias; art. 16.d) de la Ley electoral de Cantabria; art. 12.1.g) de la Ley de Castilla-La Mancha; art. 14.h) de la Ley electoral de Castilla y León; art. 15.d) de la Ley electoral de Extremadura; art. 10.d) de la Ley electoral de las Islas Baleares; art. 14.h) de la Ley electoral de La Rioja; y art. 10.d) de la Ley electoral de la Región de Murcia; el art. 13.g) de la Ley canaria opta ya por la denominación en euros, con idéntica cuantía. En Galicia, el límite se sitúa en doscientas cincuenta mil pesetas por el art. 18.h) de su Ley electoral. Madrid y Navarra no contemplan disposiciones relativas a las infracciones electorales.

10 Art. 87 de la Ley 5/1990 del País Vasco y 46 de la Ley 1/1987, valenciana.

11 Ley 39/2015, de 1 de octubre, del Procedimiento Administrativo Común de las Administraciones Públicas.

12 AAJEC de 30 de abril de 1996 y de 22 de marzo de 2001, entre otros. 
el Tribunal Supremo ${ }^{13}$, con las previsiones contenidas en el Reglamento del Procedimiento para el ejercicio de la potestad sancionadora ${ }^{14}$. Bien es verdad que en los últimos ańos parecía haberse consolidado una práctica distinta en la Junta Electoral Central ${ }^{15}$. A pesar de ello, el único instrumento indubitado disponible, y a diferencia de lo que sucede con otros procedimientos, como el del recurso contra la proclamación de electos del art. 108.3, regulado por una Instrucción de $1995^{16}$, era la práctica acuñada por los órganos de la Administración electoral, lo que en otro lugar me llevó a proponer la elaboración de una norma ad hoc por parte de la Junta Electoral Central ${ }^{17}$. En la actualidad, sin embargo, la citada Ley 39/2015 ha incorporado en su texto el grueso de las disposiciones contenidas en el Reglamento de 1993, con lo que automá-

13 STS, Sala de lo Contencioso-Administrativo, Sección 7a, de 22 de marzo de 1999, fundamento séptimo, que se refiere al citado Real Decreto como «norma de carácter reglamentario expresamente rechazada en la resolución impugnada y cuyo ámbito de aplicación no se extiende al procedimiento seguido ante la Junta Electoral Central, en desarrollo de la Ley 30/1992, pues la indicada norma reglamentaria tiene su aplicación específica para la Administración General del Estado, para la Administración de las Comunidades Autónomas y para la Administración de carácter local y, en consecuencia, procede confirmar, en este punto, el criterio mantenido por la Junta Electoral Central».

15 Véanse al efecto los AAJEC de 13 de diciembre de 2006, de 19 de junio y 3 de julio de 2008 y de 24 de julio de 2013. Por motivos similares la Junta Electoral Central no formuló ninguna objeción en alguna ocasión en que se había seguido en Juntas inferiores la tramitación ordenada por dichas normas. Tal fue el caso resuelto por AJEC de 24 de julio de 2008, cuyo apartado $5^{\circ}$ señala lo siguiente: «En el expediente sancionador no se aprecia la existencia de ninguno de los demás motivos aducidos por la recurrente, relativos a la supuesta irregularidad del procedimiento o a la vulneración de sus derechos. Se ha seguido el procedimiento establecido en el Real Decreto 1398/1993, de 4 de agosto por el que se aprueba el Reglamento del Procedimiento para el Ejercicio de la Potestad Sancionadora, iniciado mediante resolución en la que se concretaron los hechos determinantes de la apertura del expediente, mediante la remisión a los documentos que se acompañaban» (las cursivas son nuestras). Sobre esta cuestión, M. Delgado-Iribarren García-Campero (2015), «Artículo 19», en M. Delgado-Iribarren (dir.), Comentarios a la Ley Orgánica del Régimen Electoral General y a la Ley Orgánica de Referéndum, Madrid: La Ley (pág. 228).

16 Instrucción de 28 de mayo de 1995, de la Junta Electoral Central, sobre tramitación de los recursos a que se refiere el art. 108.3 de la LOREG.

17 F. Pascua Mateo (2015), «Artículo 153», en M. Delgado-Iribarren (dir.), Comentarios a la Ley Orgánica del Régimen Electoral General y a la Ley Orgánica de Referéndum, Madrid: La Ley (pág. 1297). 
ticamente se han convertido en normativa de aplicación supletoria al amparo del art. 120 LOREG. Por supuesto dicha supletoriedad se encuentra sometida al conocido requisito de que la disposición concreta sea compatible con la especial naturaleza del proceso electoral ${ }^{18}$, que impide un automatismo acrítico en la aplicación de una normativa que, por lo demás, no está pensada para la Administración electoral, que queda fuera en principio de su ámbito subjetivo de aplicación. No obstante, ha de reconocerse que la materia sancionadora es seguramente de las menos afectadas por esta especialidad, ya que, sobre todo en el caso de las Juntas de carácter permanente, esto es la Central y las de comunidad autónoma, la Administración electoral no se encuentra tan compelida por el cumplimiento estricto de los perentorios plazos electorales. En el caso de las provinciales y de zona, que se disuelven a los cien días desde la votación, quizá pudiera plantearse algún problema en el caso de una duración del procedimiento sancionador superior a su disolución, como luego se verá.

Más complicado, aunque no imposible, resulta adoptar este mismo criterio respecto de los muy importantes principios de la potestad sancionadora contenidos en los arts. 25 y siguientes de la Ley $40 / 2015^{19}$. Es cierto que la distinción entre ambas leyes es cuanto menos artificiosa y en ocasiones arbitraria, como lo prueba precisamente la ruptura de la regulación del derecho sancionador entre los principios materiales y las reglas procedimentales, a diferencia de lo que con buen criterio llevaba a cabo la Ley 30/1992 ${ }^{20}$. Sin embargo, la remisión del art. 120 LOREG se refiere exclusivamente al procedimiento $^{21}$, lo que podría darnos un indicio de sus límites. Además,

18 Puesto de manifiesto desde los momentos iniciales tras la aprobación de la LOREG, tanto por la Secretaría de la Junta Electoral Central en el Informe de 18 de noviembre de 1985 como por la doctrina. Es el caso de L. Cazorla Prieto (1986), «Artículo 120», en L. Ma Cazorla (dir.), Comentarios a la Ley Orgánica del Régimen Electoral General, Madrid: Civitas (pág. 1027).

19 Ley 40/2015, de 1 de octubre, del régimen jurídico del sector público.

20 Ley 30/1992, de 26 de noviembre, del Régimen Jurídico de las Administraciones Públicas y del Procedimiento Administrativo Común. En este sentido se ha pronunciado una muy relevante parte de la doctrina. Por centrarnos en el ámbito sancionador, podemos citar a T. Cano Campos (2016), «El autismo del legislador: la «nueva» regulación de la potestad sancionadora de la administración», $R A P, 201$, págs. 25-68. Asimismo, M. Burzaco Samper (2016), «Análisis crítico de la regulación de la potestad sancionadora en las nuevas Leyes 39/2015 y 40/2015, de 1 de octubre», Asamblea. Revista Parlamentaria de la Asamblea de Madrid, 34, págs. 103-132 (pág. 105).

21 El tenor literal, bien expresivo, es: «En todo lo no expresamente regulado por esta Ley en materia de procedimiento será de aplicación la Ley de Procedimiento Administrativo» (las cursivas son nuestras). 
con un criterio histórico puede apuntalarse una interpretación restrictiva, en la medida en que la norma en vigor a la aprobación de la LOREG era la Ley de Procedimiento Administrativo de 17 de julio de 1958, que en sus arts. 133 a 137 se limitaba a regular el «procedimiento sancionador», sin referencia alguna a los principios reguladores de la potestad sancionadora. Es la Ley 30/1992 la que los introduce con posterioridad y aun así en un capítulo aparte, el II del título IX, que integra los arts. 134 a 138. De hecho, no han faltado cualificados autores que han subrayado cómo la aplicación supletoria de dicha Ley 30/1992 en el ámbito electoral ha de centrarse especialmente en los preceptos que específicamente regulan las cuestiones procedimentales ${ }^{22}$. Ahora bien, lo cierto es que buena parte de estos principios, como los de legalidad, irretroactividad, tipicidad o culpabilidad, no dejan de ser sino concreciones del derecho a la legalidad sancionadora del art. 25 $\mathrm{CE}$ o mandatos contenidos en el art. 9.3 CE y concretados en su extensión por la jurisprudencia del Tribunal Constitucional, de forma que bajo dicha condición le son aplicables sin ninguna duda a la Administración electoral. Por lo tanto, bien podrían aplicarse con carácter supletorio las previsiones de la Ley 40/2015, considerando además que son herederas de las correspondientes de la Ley 30/1992, que sí venían aplicándose hasta la fecha. La consabida doctrina de la JEC de limitar dicha aplicación supletoria a lo no dispuesto en la LOREG y solo en la medida en que sea compatible con las especialidades del procedimiento electoral puede soslayar los inconvenientes que una aplicación completa de la nueva regulación pudiera entrañar ${ }^{23}$. De hecho, tales preceptos, junto con las disposiciones de procedimiento de la Ley 39/2015, van a permitir resolver prácticamente todas las cuestiones dudosas, algunas tan relevantes como la culpabilidad requerida para la concurrencia de responsabilidad. En este sentido, es por ejemplo relevante la supresión de la posibilidad de comisión de infracciones a título de simple

22 En este sentido, Delgado-Iribarren García-Campero (2015: 230).

23 Un argumento adicional podría encontrarse en la aplicación supletoria de otras disposiciones no expresamente referidas en el art. 120, como la hipotética de la legislación disciplinaria sobre funcionarios públicos, en particular el Reglamento de 1986, para el ejercicio de las competencias que ostentan las Juntas para exigir responsabilidad disciplinaria a las personas que intervengan con carácter oficial en las operaciones electorales en razón del art. 19.1.j) y 19.2 LOREG. Dicha aplicación ha sido sostenida por Delgado-Iribarren García-Campero (2015: 228). Lo reitera en el comentario al art. 120 en la página 1068. Hay que señalar que en alguna ocasión la JEC ha aplicado en cambio el régimen propio del Código Penal, en concreto el de prescripción de las faltas, como ocurrió en el AJEC de 18 de enero de 1994. 
inobservancia ${ }^{24}$, criterio adoptado en alguna ocasión por la Junta Electoral Central ${ }^{25}$ prevista en el antiguo art. 130 de la Ley 30/1992 y que se ha eliminado en el actual art. 28.1 de la Ley 40/2015, que exige, al menos, dolo o culpa ${ }^{26}$.

\section{III. ÓRGANOS COMPETENTES}

Como se ha señalado anteriormente, los órganos competentes para el ejercicio de las potestades sancionadoras por la Administración electoral son las Juntas electorales. Su ámbito de actuación viene delimitado en principio en razón de sus competencias, de la cuantía de la sanción a imponer y de su ámbito territorial. El primero de estos criterios es evidente, en tanto que la competencia sancionadora es aneja a la competencia material y al tercero se refiere expresamente el art. 19.2 LOREG. Más discutible puede ser calificar de criterio atributivo de competencias al de la cuantía de la sanción, puesto que en principio es más bien un límite a la capacidad de imposición de multas de cada Junta. Sin embargo, dado que la horquilla de las multas por infracción de la normativa sobre encuestas electorales se sitúa en su umbral mínimo por encima de la capacidad de las demás, resulta que indirectamente este criterio concentra en la Junta Electoral Central las competencias para sancionar este tipo de infracciones.

Un problema derivado de este diseńo competencial es el de la eventualidad de que el plazo de seis meses hoy vigente para concluir un expediente

24 Principio tan relevante que, por ejemplo, le servía de apoyatura a nuestra mejor doctrina para defender la especificidad del derecho administrativo sancionador frente al derecho penal. Véase A. Nieto (2012), Derecho administrativo sancionador, Madrid: Tecnos (pág. 347).

25 AJEC de 19 de junio de 2008, en cuyo fundamento $4^{\circ}$ se señala que «en el Derecho Administrativo Sancionador, la concurrencia de intencionalidad del infractor deja paso en múltiples casos tanto a supuestos de culpa o imprudencia, como de simple inobservancia. Concurre culpa en supuestos en que se realiza un hecho típicamente antijurídico, no intencionadamente sino por haber infringido un deber de cuidado que personalmente le era exigible y cuyo resultado debía haber previsto. Incluso, la simple inobservancia de la ley puede producir responsabilidad, en los términos reconocidos en el citado artículo 130.1 de la Ley 30/1992».

26 De precipitada califica esta supresión M. Casino Rubio (2015), «La potestad sancionadora de la Administración y vuelta a la casilla de salida", Documentación Administrativa, nueva época, 2, para quien casa mal con las leyes sectoriales que permiten la comisión de infracciones a título de simple inobservancia. 
sancionador (art. 21.2 de la Ley 39/2015) genera un efecto negativo a la hora de la resolución de la mayor parte de los expedientes, por las peculiaridades de la Administración electoral, en este caso el carácter meramente temporal de las Juntas provinciales y de zona, que se disuelven automáticamente a los cien días de la jornada de votación (art. 15.2 LOREG) y que ha motivado que con toda frecuencia sea la Junta Electoral Central la que deba hacerse cargo de una instrucción ya iniciada pero aún no concluida ${ }^{27}$ o bien de la resolución de un recurso competencia de una Junta inferior ${ }^{28}$. Además del riesgo de caducidad que ello puede comportar, es evidente que semejante traslado altera el régimen de distribución de competencias diseñado por la Ley, puede generar un interés dilatorio en la Junta territorial competente ${ }^{29}$ y provoca disfunciones de cierta gravedad como lo es el cambio de instructor a mitad del procedimiento, además de reducir los recursos en vía administrativa, por cuanto no hay órgano superior a la Junta Central. Incluso se ha dado la circunstancia de expedientes recurridos que, habiendo llegado a la Junta Electoral Central, han tenido que ser devueltos por esta a la de origen por haberse convocado un nuevo proceso electoral y constituirse, en consecuencia, nuevamente las Juntas provinciales y de zona ${ }^{30}$. Por tanto, solo en el caso de los procedimientos incoados por las Juntas de comunidad autónoma y por la propia Central existe una certeza de que el órgano sancionador va a poder concluir su trabajo. Una posible solución, sin alterar el carácter temporal de las Juntas inferiores, sería la reducción del tiempo máximo de duración del procedimiento sancionador que podría incluir la Instrucción de la Junta Electoral Central a la que nos hemos referido anteriormente.

En cualquier caso, aunque no se indica así en el art. 19 LOREG, más allá de los límites para la imposición de sanciones, la capacidad para sancionar por parte de las Juntas electorales viene determinada por su propio ámbito material de competencias, de manera que si en el ejercicio de estas detectan alguna vulneración de la LOREG que pueda ser constitutiva de infracción deberán

27 Los acuerdos en los que se adopta una decisión semejante son habituales. A título de ejemplo valgan los diversos AAJEC de 3 de julio de 2008, y el AJEC de 6 de mayo de 2010.

28 Tal fue el caso del recurso resuelto por AJEC de 3 de julio de 2008 contra una sanción impuesta al entonces alcalde de Sevilla por la Junta Electoral de zona. La Junta Electoral Central decidió asumir la competencia que de no estar disuelta le hubiera correspondido a la Provincial de Sevilla. Asimismo, AJEC 76/2012, de 10 de mayo.

29 De hecho, no han faltado acuerdos de la Junta Electoral Central censurando la lentitud en la tramitación de los expedientes sancionadores de algunas Juntas inferiores, como sucede con el AJEC de 22 de marzo de 2012.

30 Véase AJEC de 29 de septiembre de 2011. 
incoar el expediente sancionador correspondiente. No ha sido este un tema demasiado controvertido, si bien la Junta Electoral Central ha tenido ocasión de aportar algún criterio concreto, como es la atribución a las Juntas de zona competentes por razón del territorio para el ejercicio de la potestad sancionadora contra los alcaldes por infracción del art. 50.3 LOREG ${ }^{31}$. En otras ocasiones se ha ordenado el archivo de actuaciones por versar la denuncia correspondiente sobre materias ajenas a la competencia de la Administración electoral $^{32}$.

Por otra parte, aunque se trate de algo excepcional, hay que señalar que en ocasiones se han producido actuaciones de otras administraciones públicas con carácter sancionador que están relacionadas con actos electorales, si bien en aplicación de otras disposiciones normativas. Es el caso de la Agencia de Protección de Datos, que ha sancionado la utilización de los incluidos en el censo electoral para fines comerciales - conducta prohibida en el art. 41 LOREG - por infracción de las normas reconocidas en la Ley Orgánica 15/1999, de 13 de diciembre ${ }^{33}$ y tras haber recibido respuesta de la Junta Electoral Central a sendas consultas en la que se denegaba el acceso público a los citados datos censales ${ }^{34}$. Asimismo, el de las sanciones por infracciones de los límites establecidos en la normativa sobre gastos electorales, que corresponden, en una discutible decisión, al Tribunal de Cuentas, según se analizará detenidamente más adelante. En cambio, los órganos jurisdiccionales han tenido ocasión de rechazar la asunción de competencias sancionadoras en materia electoral por otras Administraciones públicas, como las corporaciones locales ${ }^{35}$.

Para concluir con este apartado ha de destacarse, frente a lo que sucedió con alguna de nuestras leyes históricas ${ }^{36}$, la falta de competencias sancionadoras en manos del presidente de la Mesa Electoral. Es cierto que la LOREG otorga a este órgano una especial relevancia en el seno de la Mesa al reconocerle la condición de autoridad pública (art. 91.1) y conferirle la potestad del

31 AJEC de 27 de octubre de 2011.

32 AJEC de 22 de marzo de 2012.

33 Y cuya corrección ha sido ratificada por el Tribunal Supremo. Véase STS, Sala Tercera, de lo Contencioso-Administrativo, Sección 6a , de 7 de marzo de 2006.

34 AAJEC de 2 de octubre de 1995 y 22 de enero de 1996.

35 STSJ del País Vasco, Sala de lo Contencioso-Administrativo, de 13 de julio de 2000, que anula una resolución del Ayuntamiento de Portugalete en la que, al amparo de una ordenanza sobre publicidad no comercial, se sancionaba a Herri Batasuna por haber colocado carteles electorales fuera de los espacios autorizados.

36 El art. 108 de la Ley electoral de 1890 disponía que: «Los Alcaldes y los Presidentes de Colegio electoral ó de Juntas de escrutinio, y las Juntas municipales, no podrán imponer multa que exceda de 100 pesetas». 
mantenimiento del orden en el local de votación (art. 93), para lo cual puede dirigir instrucciones a los agentes de las fuerzas y cuerpos de seguridad del Estado allí destacados (art. 92). Sin embargo, ello no supone que se dicten actos administrativos de naturaleza sancionadora, sino tan solo el ejercicio de una actuación de mantenimiento o restauración de lo que con acierto se ha calificado de "condiciones ambientales de la votación» ${ }^{37}$.

\section{LA DEFECTUOSA TIPIFICACIÓN DE LAS CONDUCTAS INFRACTORAS}

A pesar de que anteriormente hemos señalado que la concurrencia de las leyes 39 y 40/2015 permite completar de manera bastante razonable el régimen sancionador de la LOREG, no puede dejar de subrayarse la deficiente redacción del art. 153, muy similar a la que ya aparecía en el art. 93 del Real Decreto Ley 20/1977 y que fuera objeto, por este motivo, de críticas doctrinales cualificadas ${ }^{38}$ respecto del principio de tipicidad contemplado en el art. 25.1 CE. La única mejora es la eliminación de la referencia a las normas que desarrollen la ley que, al menos, supone respetar la reserva de ley propia de la materia sancionadora. En cambio, y paradójicamente si se tiene en cuenta el desarrollo de los controles de la Administración a lo largo de los últimos decenios, la normativa actual mira con desventaja sus precursoras de $1890 \mathrm{y}$ 1907, que sí tipificaban varias conductas infractoras de manera absolutamente precisa.

Es, desde luego, plausible dudar de la constitucionalidad de esta norma debido a la laxitud de la fórmula empleada, a pesar de que con la mejor voluntad la Junta Electoral Central ha señalado que el texto estudiado cumple con las exigencias derivadas del art. 25.1 $\mathrm{CE}^{39}$. Recordemos que, de acuerdo con una consolidada jurisprudencia del Tribunal Constitucional, la ley sancionadora ha de contener los elementos esenciales de la conducta antijurídica y la naturaleza y límites de las sanciones a imponer ${ }^{40}$. Además, deben delimitarse los criterios para la gradación de las sanciones y para establecer la correspon-

37 L. Gálvez Muñoz (2009), La confección del voto, Madrid: CEPC (pág. 70).

38 L. M. Cosculluela Montaner y S. Muñoz Machado (1979), Las elecciones locales. (Comentarios a la Ley 39/1978, de 17 de julio), Madrid: El Consultor de los Ayuntamientos y de los Juzgados (pág. 91).

39 AJEC de 1 de junio de 2004, entre otros.

40 SSTC 132/2001, de 8 de junio, FJ 4 y 26/2005, de 14 de febrero, FJ 5, por referirnos a algunas de las más recientes. 
dencia entre la gravedad de la conducta y la sanción, pues en caso contrario «se estaría dejando libertad absoluta, no solo un margen de discrecionalidad, al aplicador del derecho, que concebiría la misma como una decisión singular, una graduación ad hoc que en cada caso concreto lleva a cabo la misma autoridad que impone la sanción $»^{41}$. Es cierto que el art. 153 cumple con uno de los requisitos esenciales, como es el de la determinación de la naturaleza — multa pecuniaria - y del límite máximo de la sanción que se fija con carácter general en una horquilla que oscila de modo general entre trescientos y tres mil euros si los autores son funcionarios públicos - concepto este precisado en el art. 135- y entre cien y mil euros, si son particulares. Qué duda cabe de que se respeta, asimismo, el principio non bis in idem, al excluir la sanción por infracción de las conductas constitutivas de delito, por lo que, advertida por la Administración electoral la posible concurrencia de una infracción penal, deberán abstenerse de continuar el expediente iniciado hasta que exista un pronunciamiento en esta sede ${ }^{42}$.

Sin embargo, resulta complicado precisar a partir del art. 153.1 LOREG las conductas constitutivas de infracción de modo que aparezca la necesaria "definición básica de la conducta prohibida en la propia ley» ${ }^{43}$, sobre todo en lo que pueda entenderse por normas obligatorias. Ello a pesar de que la Junta Central lo haya estimado - al menos en los acuerdos sancionadores dictados hasta la fecha - tipificación suficiente a los efectos del art. $25.1 \mathrm{CE}^{44}$, postura asumida también por el Tribunal Supremo para el que la conexión entre el art. 153.1 LOREG y otros preceptos específicos de la misma norma, explicitada

41 SSTC 207/1990, de 17 de diciembre, FJ 3 y 129/2006, de 24 de abril, FJ 4, entre otras.

42 Criterio que la JEC ha aplicado desde hace tiempo, como sucedió con el Acuerdo 383/1994, de 18 de noviembre, que resolvió con relación a una denuncia de un funcionario de Correos que «estando pendiente que recaiga la resolución judicial oportuna, no procede en este momento la apertura por esta instancia de expediente disciplinario». Asimismo, AJEC 381/1996, de 27 de septiembre, por el que, constatado mediante providencia que determinada conducta no resultaba delictiva por no darse el requisito del dolo, se solicita al Ministerio del Interior que comunicase si la Administración penitenciaria tenía conocimiento del traslado de un recluso al que se le privó del derecho de voto por correspondencia. Sí es en cambio recomendable incoar expediente sancionador y proceder a su suspensión inmediata con el fin de interrumpir los plazos de prescripción de las infracciones por si al final no se apreciara la comisión de un delito, pero pudiera concurrir responsabilidad sancionadora.

43 STC 60/2000, de 2 de marzo, FJ 4.

44 Se trata de una doctrina reiterada que aparece, entre otros, en el AJEC de 19 de enero de 1997. 
por el órgano sancionador, es suficiente para que «concurra la tipicidad» ${ }^{45}$, y aceptada por nuestra mejor doctrina, que, sin embargo, se queja del exceso con el que el legislador acude a este recurso ${ }^{46}$.

El propio Tribunal Constitucional, si bien en un contexto algo ajeno como es el derecho parlamentario sancionador, y con una cierta quiebra de su jurisprudencia previa, ha venido a dar cobijo a una práctica similar en la STC 129/2006, en cuyo fundamento 5 señala que «no toda indeterminación de la disposición sancionadora conduce de forma inexorable a la vulneración del derecho a la legalidad sancionadora", pues se ha de tener en cuenta que el mismo «en su faceta de exigencia de predeterminación suficiente de las conductas sancionables está íntimamente relacionado con la seguridad jurídica de modo que su fundamento reside en que el ciudadano no se vea sorprendido con una actuación sancionadora imprevisible» ${ }^{47}$, ya que es condición del ejercicio de la propia libertad conocer las consecuencias jurídicas de los propios actos, de modo que el ciudadano pueda acomodar su conducta a las previsiones normativas. En este caso se estimó suficiente que la Constitución estableciese que el voto es indelegable (art. 79.3) para considerar previsible la sanción por pulsar el botón de presencia de otro diputado autonómico, aun sin llegar a votar efectivamente. Por el contrario, la STC $61 / 1990^{48}$ estima que no se puede afirmar que se cumpla con la exigencia de la predeterminación normativa del comportamiento sancionable con una referencia que no mencione de manera precisa las conductas infractoras y se limite a una «formulación vaga» de lo dispuesto en la norma.

Sea como fuere, semejante regulación entraña una defectuosa técnica normativa que debiera corregirse y obliga en todo caso al órgano sancionador a explicitar claramente la norma obligatoria infringida, con indicación del artículo en el que se halla, y a que se haga una interpretación estricta de la misma ${ }^{49}$. Es evidente que en ocasiones la calificación como infracción admi-

45 STS, Sala de lo Contencioso-Administrativo, Sección 7ª, de 15 de diciembre de 1997 , fundamento noveno.

46 En este sentido A. Nieto (2012: 277 y ss.). En cambio, se inclinan por la inconstitucionalidad de este tipo de tipificaciones genéricas P. González Tobarra y J. R. Jiménez Carbajo (2009), "Capítulo I», en Manual de Derecho administrativo sancionador, Tomo I, Cizur Menor: Abogacía General del Estado. Dirección del Servicio Jurídico del Estado, Ministerio de Justicia, Thomson Reuters-Aranzadi (págs. 142 y ss.).

47 También SSTC 151/1997, de 29 de septiembre, FJ 3 y 24/2004, de 24 de febrero, FJ $2 \mathrm{~b})$.

48 STC 61/1990, de 29 de marzo, FJ 9.

49 De «pura y simplemente inaceptable» lo califica con razón J. L. Peñaranda Ramos (1986), Artículo 153, Comentarios a la Ley Orgánica del Régimen Electoral General, 
nistrativa es clara y taxativa, como ocurre con el art. 132.4, que atribuye a la Junta Central y a las juntas provinciales la sanción de las vulneraciones de las normas sobre gastos y subvenciones electorales que no constituyan delito, pero tales casos son minoritarios. Sin necesidad de ser tan taxativa, en otras ocasiones la legislación es suficientemente clara como para deducir las existencia de una obligación o de una prohibición, para lo cual es asimismo lícita la colaboración con los reglamentos, singularmente las instrucciones aprobadas por la Junta Electoral Central, como sucede con la interpretación de los actos prohibidos durante el período electoral que no se incluye dentro de los límites temporales de la campańa electoral, perfectamente delimitada por la instrucción $3 / 2011^{50}$. También es posible interpretar en otros supuestos lo que pueda ser infracción electoral como realización culposa de las conductas que se tipifican como delito electoral si se cometen dolosamente (arts. 139, $140,141,142$ y 145), aunque nada le hubiera costado al legislador expresarlo así. Sin embargo, pese a ello restan multitud de conductas que contrarían las obligaciones impuestas por la LOREG respecto de las cuales la inducción de la infracción es más compleja.

Un claro ejemplo es el de las campańas institucionales en las que se fomente la participación, práctica reiteradamente prohibida por la Junta Electoral Central a partir de la previsión del art. 50.1 de que la misma no puede orientar el sentido del voto ${ }^{51}$. Esta norma, que es incuestionablemente obligatoria, no parece tan clara sin la interpretación pertinente ${ }^{52}$ y puede plantear dudas si pretende utilizarse como fundamento de una sanción. Así lo ha entendido, de hecho, la Junta Electoral Central al rechazar la incoación de expediente sancionador contra la Generalidad de Cataluña por infracción de este precepto, al «considerar apreciable en la Generalidad de Cataluña duda

Madrid: Civitas (pág. 1259). Muy crítico se muestra también E. Arnaldo Alcubilla (1994), «La Administración electoral española. Naturaleza y competencias de la Junta Electoral Central», Revista Vasca de Administración Pública, 40, diciembre, 71-102 (pág. 97).

50 Instrucción 3/2011, de 24 de marzo, de la Junta Electoral Central, sobre interpretación de la prohibición de realización de campaña electoral incluida en el artículo 53 de la Ley Orgánica del Régimen Electoral General.

51 AJEC de 24 de mayo de 2006.

52 Ni siquiera la Instrucción de 13 de septiembre de 1999 prescribe terminantemente la prohibición de incentivar la participación que puede deducirse, no obstante, a sensu contrario, de la mención a las campañas en este sentido que puedan llevarse a cabo al amparo de la legislación electoral autonómica, así como de la eliminación como contenido de la campaña institucional del fomento de la participación prevista en la redacción inicial del art. 50.1 LOREG por medio de la Ley Orgánica 13/1994. 
razonable de interpretación jurídica acerca de la licitud o ilicitud $»^{53}$ de una campaña institucional que promovía la participación durante el referéndum de ratificación de la reforma de su Estatuto de Autonomía, que, por lo demás, fue declarada ilegal, «duda que excluye la responsabilidad infractora ${ }^{54}$. Solo la reiteración de la infracción, una vez que la Junta Electoral Central se había pronunciado claramente al respecto, motivó la incoación de expediente sancionador, resuelto, por lo demás, con la imposición de una multa de seiscientos euros, contra el entonces presidente de la Generalidad ${ }^{55}$.

Más discutible es, finalmente, que la falta de una clasificación de las infracciones atendiendo a su gravedad ${ }^{56}$ dé cumplimiento al mandato de proporcionalidad, no tanto en la aplicación de la sanción, sino en su predeterminación, si bien la previsión de los límites mínimo y máximo y, sobre todo, la aplicación supletoria de los criterios que al efecto aparecen en el art. $29.3 \mathrm{de}$ la Ley 40/2015 puede aliviar los defectos de la LOREG, sobre todo si la Junta correspondiente da buena respuesta al mismo en el momento de aplicar la sanción, por cuanto el Tribunal Constitucional se muestra reacio a estimar el amparo si el perjuicio invocado no ha sido efectivo ${ }^{57}$.

La propia Junta Electoral Central, en su Informe de 20 de enero de 2009, aun sin pronunciarse sobre la constitucionalidad o no del art. 153 LOREG, destaca expresamente que «el sistema establecido originariamente

53 Duda justificada además en la falta entonces de carácter básico del art. 50 LOREG. Sin embargo, la remisión a la misma como norma supletoria por el art. 11.1 de la Ley Orgánica 2/1980, de las distintas modalidades de referéndum, así como por las disposiciones aprobadas periódicamente por la Generalidad, permitía entender aplicable esta prohibición. En la actualidad, tras la reforma de la disposición adicional primera LOREG por la Ley Orgánica 2/2011, de 28 de enero, es indudable dicho carácter básico y, por tanto, la prohibición de que la campaña institucional fomente la participación.

54 AJEC de 12 de junio de 2006.

55 AJEC de 22 de junio de 2006, resuelto por AJEC de 13 de diciembre de 2006. Más recientemente, por AJEC de 1 de febrero de 2007, se acordó incoar expediente sancionador contra el viceconsejero de Gobernación de la Junta de Andalucía, por un motivo similar, ocurrido durante la campaña del referéndum de ratificación de la reforma del Estatuto de Autonomía de esta comunidad. En este caso el resultado le fue favorable al expedientado, ya que no se apreció responsabilidad administrativa. Quedan exentas de este reproche las infracciones del régimen de encuestas que, al aparecer tipificadas con una sanción mayor, resultan indiscutiblemente más graves.

57 SSTC 210/2005, de 18 de julio, FJ 3 y 129/2006, FJ 4. Tampoco el Tribunal Supremo ha querido pronunciarse sobre la infracción de este principio, a pesar de que se le ha planteado, si bien por defectos procesales de la alegación. STS, Sala de lo ContenciosoAdministrativo, Sección 7a, de 30 de diciembre de 2002, fundamento segundo. 
en la LOREG no parece el más acorde con las exigencias de tipicidad del Derecho Administrativo sancionador, especialmente en cuanto a la garantía material — predeterminación normativa del tipo- y a la garantía formal rango de la norma sancionadora-, en la forma que se infiere, según reiterada jurisprudencia constitucional, del contenido del art. 25.1 de la CE, y, además, resulta de escasa eficacia disuasoria». Consecuentemente propone «establecer una graduación de los diferentes tipos de infracciones, distinguiendo al menos entre infracciones muy graves, graves y leves», así como "la tipificación expresa de las acciones u omisiones que se estimen constitutivas de infracción (pudiendo quedar las de carácter leve como una categoría residual, con una enunciación análoga a la del art. 153.1)». En cuanto a las sanciones, se sugiere su graduación «adaptando las cuantías de las multas a la gravedad de las infracciones (incluso con algún tipo de sanción no meramente económica, como por ejemplo la difusión pública de la sanción impuesta)» y aprovechar para convertir a euros la cuantía de unas multas aún especificadas en pesetas ${ }^{58}$.

\section{REGULACIÓN DE LAS SANCIONES}

\section{UN SISTEMA DE SANCIONES INEFICAZ}

Naturalmente si una tipificación tan escasamente compatible con las garantías constitucionales no ha sido objeto de impugnación ante el Tribunal Constitucional la razón hay que buscarla en la levedad de las sanciones, que no ofrecen un contra estímulo suficiente ante la comisión de una conducta infractora. Aun con el muy ligero agravamiento de las sanciones llevado a cabo por la Ley Orgánica 2/2011, la única sanción prevista, la de multa, y su escasa cuantía, un máximo de 30000 euros en el caso de vulneración de la normativa reguladora de la difusión de encuestas electorales, 3000 en los demás supuestos, no disuaden a quien pretende ignorar las prohibiciones de la LOREG. Ni siquiera pueden las Juntas acordar la reparación del daño causado, a pesar de que así parezca permitirlo el art. 130.2 de la Ley 30/1992, que declara compatibles las responsabilidades administrativas que se deriven del procedimiento sancionador con «la exigencia al infractor de la reposición de la situación alterada por el mismo a su estado originario, así como con la indemnización por los daños y perjuicios causados que podrán ser determinados por el órgano competente», redacción mantenida en el art. 28.2 de la Ley 40/2015. Al margen de que este precepto ha sido entendido tradicionalmente

58 Informe de la JEC de 20 de enero de 2009, pág. 36. 
por la doctrina como un instrumento para reparar los perjuicios ocasionados a la Administración (cosa que sí pueden hacer las Juntas mediante un procedimiento complementario a tenor de lo dispuesto ahora en el art. 90.4 de la Ley 39/2015) pero no a los particulares ${ }^{59}$, de la propia LOREG se infiere un principio distinto, al menos para casos concreto, como se demuestra en el caso de infracción de la normativa sobre gastos electorales.

En efecto, aunque el art. 132.4 LOREG dispone que «las mismas Juntas sancionarán las infracciones en esta materia, conforme a lo dispuesto en el artículo 153", sin embargo, a la hora de determinar una consecuencia accesoria como la no adjudicación o reducción de la subvención estatal a la formación en la que concurran irregularidades en su contabilidad o violación de las restricciones establecidas en materia de ingresos o gastos electorales, el órgano competente para proponerlas es el Tribunal de Cuentas (art. 134.2). Ello, por supuesto, no significa que no pueda sancionarse, y de hecho la Junta Electoral Central ha mostrado un creciente activismo en reprimir algunas de las conductas relacionadas con los gastos electorales, singularmente el retraso en el plazo de entre cien y ciento veinticinco días desde la votación para la remisión de las cuentas al Tribunal de Cuentas por parte de las candidaturas con derecho a recibir subvenciones estatales o que hubieran solicitado adelantos con cargo a estas (art. 133 LOREG). Así, en diversos acuerdos de 24 de julio de 2013 se sanciona a distintos administradores generales de candidaturas tras los respectivos expedientes, por los retrasos comunicados a la Junta por el Tribunal de Cuentas. En la misma fecha se resolvieron también algunos expedientes en los que se sancionaron a varias empresas que, con infracción del plazo estipulado en el art. 133.5, no habían remitido la información correspondiente a la facturación remitida a las candidaturas por gastos electorales superiores a 10000 euros.

Se hace necesaria, por tanto, una reforma en la línea apuntada por la Junta Electoral Central que acabamos de reproducir, con una graduación de las sanciones en función de la gravedad de las conductas infractoras, una elevación de las cuantías de las multas y la posibilidad de anudar otros efectos a la sanción. En primer término, resultaría sumamente útil disponer la obligación de la Junta sancionadora de publicar en el Boletín Oficial del Estado las sanciones

59 En este sentido, E. García de Enterría y T. R. Fernández (2008), Curso de Derecho Administrativo II, Madrid: Thomson-Civitas (págs. 201 y ss.) y J. A. Santamaría Pastor (2015), Principios de Derecho Administrativo General II, Madrid: Iustel (págs. 432 y 433). Una postura contraria se sostiene con la nueva ley en A. Huergo Lora (2015), «Sanciones administrativas y responsabilidad civil. La Ley 40/2015 cambia las reglas del juego», El Almacén del Derecho, disponible en: http://almacendederecho.org/ sanciones-administrativas-y-responsabilidad-civil/. 
impuestas —al menos las que revistieran carácter de grave o muy grave- una vez que se pusiera fin a la vía administrativa, tal y como se prevé, por ejemplo en los arts. 304 y 308 de la Ley del Mercado de Valores ${ }^{60}$. El daño reputacional causado a los sancionados podría ser muy útil a efectos disuasorios, tanto más que, al no tratarse en sí de una sanción, no prosperaría, como no lo hacen en otros sectores administrativos, la solicitud de suspensión cautelar de dicha publicación, que iría además muy cercana en el tiempo a la infracción cometida. En tal sentido se ha pronunciado el Tribunal Supremo en una sentencia de $2009^{61}$, relativa a la extensión a las infracciones graves del deber de publicación de las sanciones determinada por la Ley 44/2002, en la que señala que este no tiene naturaleza sancionadora ni restrictiva de derechos individuales, sino que «se justifica por motivos de tutela jurídica de intereses públicos vinculados con el deber de información, con la finalidad de preservar los principios de transparencia y publicidad de la actividad financiera, con el objetivo de promover y reforzar la confianza de los operadores económicos y los inversores».

En la misma línea, y tal y como se prevé en disposiciones como el art. 37.1.m) de la Ley 3/2013, de 4 de junio, de creación de la Comisión Nacional de los Mercados y de la Competencia, podría establecerse la obligada publicidad de la incoación de los expedientes sancionadores, medida que, al coincidir en muchos casos con el propio período electoral, supondría un arma indudable para mantener la legalidad de la actuación de las fuerzas políticas y demás sujetos que puedan intervenir en el proceso. Por supuesto, y en aras a no interferir indevidamente en las elecciones, y a respetar los derechos de los expedientados, sería necesario que, con carácter previo a la apertura del expediente, se llevara a cabo una información reservada que permitiera una acreditación liminar de la conducta infractora. Por último, sobre todo en el caso de infracciones cometidas por medios de comunicación - especialmente previsibles en el caso de las restricciones a la difusión de encuestas electorales-, resultaría de utilidad establecer una obligada difusión de la sanción en el propio medio.

Resulta en cambio complicado considerar la introducción de otros tipos de sanción, más allá de las prohibiciones para contratar o para acceder a procesos selectivos de personal al servicio de las administraciones públicas o incluso de percepción de subvenciones, antes referidas. En primer término, no es posible, a diferencia de lo que sucede en otros ámbitos sancionadores, establecer una inhabilitación para el ejercicio de los derechos de sufragio activo o pasivo a los infractores, incluso ante la comisión de las modalidades

60 Texto Refundido aprobado por Real Decreto Legislativo 4/2015, de 23 de octubre.

61 STS, Sala de lo Contencioso-Administrativo, Sección 3a, de 21 de junio de 2009, fundamento tercero. 
más graves. La razón, obviamente, es el carácter de derecho fundamental del sufragio, del que solo una sentencia judicial firme puede privar a su titular, por lo que, con buen criterio, el art. 137, aunque incluido en la sección relativa a las disposiciones generales del capítulo VIII, limita la inhabilitación especial para el derecho de sufragio activo y pasivo a los «delitos» a los que se refiere dicho capítulo. Tampoco resulta conveniente el apercibimiento público. En este caso, si se configurara como sanción, en lugar de como obligación de la Junta sancionadora, tal y como acabamos de defender, sería sencillo en un eventual recurso contencioso-administrativo pedir su suspensión cautelar, y a un Tribunal le resultaría más complicado denegar esta medida, con el retraso consiguiente para su eficacia, por más que, evidentemente, en caso de estimación del recurso el perjuicio causado podría repararse con una publicación de la sentencia favorable y, en su caso, una indemnización económica.

\section{LA GRADUACIÓN DE LAS SANCIONES}

Una última cuestión que conviene al menos apuntar es el sistema de graduación de sanciones. Evidentemente la levedad de las cuantías de las multas permite una mayor dureza para agotar el margen legal sin demasiado peligro de que la jurisdicción contencioso-administrativa estime un hipotético recurso por falta de proporcionalidad, más aún cuando el art. 29.2 de la Ley 40/2015 exige que: «El establecimiento de sanciones pecuniarias deberá prever que la comisión de las infracciones tipificadas no resulte más beneficioso para el infractor que el cumplimiento de las normas infringidas». Con todo, ha de recordarse la aplicabilidad de los criterios generales contenidos en el art. 29.3, que reconoce como criterios de graduación de la sanción el grado de culpabilidad, la existencia de intencionalidad, la continuidad en la conducta infractora, la naturaleza de los perjuicios causados y la reincidencia, por comisión en el término de un año de más de una infracción de la misma naturaleza cuando así haya sido declarado por resolución firme en vía administrativa. Lo mismo cabe señalar del resto de principios previstos en dicho artículo, como el concurso de infracciones o las infracciones continuadas. En fin, resulta conveniente una motivación del grado en el que se ha impuesto la sanción, más aún cuando se supere el tercio inferior o grado mínimo, que la jurisprudencia viene considerando como un cierto «umbral de seguridad», dentro del cual se admite un margen de discrecionalidad por parte del órgano sancionador ${ }^{62}$.

62 Entre otras muchas, SAN, Sala de lo Contencioso-Administrativo, Sección Sexta, de 22 de octubre de 2010, confirmada posteriormente por STS, Sala Tercera, de lo Contencioso-Administrativo, Sección 3a , de 29 de abril de 2013. 
En el caso específico de la Administración electoral, en la imposición de sanciones se cumple habitualmente el principio de motivación, si bien, precisamente por la apuntada suavidad de las sanciones legalmente previstas, se tiende en los últimos tiempos a aplicar unos criterios algo más rigurosos a la hora de agotar el margen disponible, de manera que, en caso de que no concurran circunstancias agravantes ni atenuantes, el criterio es imponer la sanción en su grado medio ${ }^{63}$, mientras que se han impuesto sanciones dentro del tercio superior, aun habiendo concurrido circunstancias agravantes y atenuantes ${ }^{64}$. Ello no implica, por supuesto, que la Administración electoral no haya apreciado en ocasiones desproporción en la sanción, de modo que pueden encontrarse acuerdos en los que, al rechazarse la apreciación de una agravante considerada por la Junta inferior, se reduce la cuantía de la multa a su grado mínimo ${ }^{65}$.

\section{PRESCRIPCIÓN DE INFRACCIONES Y SANCIONES}

En cuanto al plazo de prescripción, debido a la ausencia de disposiciones al efecto en la LOREG y en la Ley de Procedimiento Administrativo de 1958, durante mucho tiempo hubieron de aplicarse términos contemplados en otras disposiciones sancionadoras, en particular el de dos meses establecido en el art. 113 del Código Penal para las faltas ${ }^{66}$, hoy fijado en seis meses por el

63 Véanse diversos AAJEC de 24 de julio de 2013. Este criterio supone endurecer alguna línea anterior que reservaba el grado medio a la concurrencia de alguna circunstancia agravante e incluso impuso sanciones dentro del tercio inferior, bien que en su mitad superior, aun apreciando dos circunstancias agravantes. Véanse en este sentido el fundamento $6^{\circ}$ del AJEC de 19 de junio de 2008 y del AJEC de 3 de julio de 2008.

64 AJEC de 24 de julio de 2013, que impone una sanción a la administradora general de la candidatura «Partido Andalucista-Espacio Plural Andaluz» de 800 euros sobre un máximo de 1000 al apreciar como circunstancia agravante el especial conocimiento de la normativa que se presume en una fuerza política de cierta experiencia en la práctica electoral y como atenuante la posterior actuación diligente a requerimiento de la Junta Electoral Central en entregar sin dilación una contabilidad electoral de cierta complejidad.

65 AJEC de 6 de noviembre de 2008. En este caso la Junta Electoral Central consideró acertadamente que no procedía apreciar como agravante la condición de autoridad del expedientado, en la medida en que dicha condición era requisito para el cumplimiento del tipo, puesto que se trataba de una infracción de los límites establecidos en el art. 50.3 LOREG para las campañas institucionales. En consecuencia, rebajó la multa al mínimo de 120 euros que en ese momento regulaba el art. 153.1 LOREG.

66 AJEC de 10 de febrero de 1992. 
art. 131.2 del Código de $1995^{67}$. Con la aprobación de la Ley 30/1992 pasó a utilizarse su art. 132 de la Ley 30/1992, que lo extendió considerablemente, puesto que, para las infracciones leves era de seis meses, término que se elevaba a dos años para las graves y a tres para las muy graves y que no han cambiado con la Ley 40/2015 (art. 30.1). Parece sensato, y así lo ha considerado la $\mathrm{JEC}^{68}$, que, puesto que la LOREG no distingue categorías de infracciones, se aplique el plazo previsto para las infracciones leves, por ser el menos gravoso y coincidir con el regulado para las faltas. Con el mismo criterio, el plazo de prescripción de las sanciones es de un año.

Dicho plazo comienza a computar a partir del momento en que se comete la conducta punible. No obstante, aunque nada se dice en la LOREG, resulta aplicable supletoriamente la doctrina relativa a las infracciones permanentes y continuadas, recogida en el art. 30.2 de la Ley 40/2015, que retrasan respectivamente el inicio del cómputo del plazo de prescripción al momento en que deja de producirse la acción u omisión típica o al de comisión de la última de las actuaciones que integren el plan preconcebido o la idéntica ocasión. Recuérdese que dentro de las primeras se incorporan aquellas conductas en las que la infracción se prolonga en el tiempo como consecuencia exclusiva de la voluntad del autor ${ }^{69}$, mientras que por infracción continuada se entiende aquella que consiste en una serie de actos concatenados que no constituyen infracciones independientes por obedecer a un único plan preconcebido o cometerse aprovechando una ocasión idéntica.

\section{EL PROCEDIMIENTO SANCIONADOR}

\section{INICIACIÓN}

La iniciación del procedimiento sancionador, como es evidente, se produce siempre de oficio, por acuerdo del órgano competente adoptado por propia iniciativa o, lo que es mucho más frecuente, previa denuncia normalmente de

67 Aprobado por Ley Orgánica 10/1995, de 23 de noviembre.

68 AJEC 41/2001, de 22 de marzo, que rechazó incoar un expediente sancionador por prescripción de unos hechos denunciados que habían acaecido un año antes.

69 Acerca de esta cuestión véase A. de Palma del Teso (2001), «Infracciones administrativas continuadas, las infracciones permanentes, las infracciones de estado y las infracciones de pluralidad de actos: distinción a efectos del cómputo del plazo de prescripción», REDA, 112, págs. 553-574 (págs. 558 y ss.); R. Caballero Sánchez (2010), «Prescripción de infracciones y sanciones», en B. Lozano (dir.), Diccionario de sanciones administrativas, Madrid: Iustel (pág. 648), y Nieto (2012: 543 y ss.). 
alguna de las fuerzas políticas que presentan candidaturas ${ }^{70}$. Durante un tiempo, dado que no se consideraba aplicable el Reglamento de 1993, se entendió que no era preciso que la denuncia cumpliese estrictamente con todos los requisitos establecidos en su art. 11 para ser considerada como tal, si bien había de reunir un contenido mínimo que incluía la identificación del presunto responsable, del propio denunciante y de los hechos denunciados, con la aportación de los medios de prueba que se estimen convenientes. En la actualidad, con la elevación a ley de los contenidos de dicho Reglamento, es indudable, como se ha señalado anteriormente, su posible aplicación supletoria, salvando la cláusula de que la disposición concreta sea compatible con la naturaleza del proceso electoral. De todos modos, sin necesidad de invocar esta cautela, podemos ya excluir algunas de las novedades de la Ley 39/2015, como el sistema de clemencia previsto en el art. 62.4, que, de una lectura literal, resulta de aplicación solo en las denuncias en las que se invoque «un perjuicio en el patrimonio de las Administraciones Públicas» ${ }^{71}$, supuesto de difícil concurrencia, con la excepción, tal vez, de la vulneración de la normativa sobre subvenciones electorales. En cualquier caso, como en el resto de los procedimientos, la condición de denunciante no otorga la de parte en el procedimiento, por más que sí deba dársele traslado de la decisión de iniciar o no actuaciones ${ }^{72}$.

\section{TRAMITACIÓN}

Una vez iniciado el expediente se nombra de inmediato un instructor y un secretario y se notifica al afectado para que formule las alegaciones que

70 Naturalmente, es posible abrir antes el trámite de actuaciones previas de carácter reservado, al que nos hemos referido más arriba,, acordado por la Junta competente y dirigido «a determinar, con la mayor precisión posible, los hechos susceptibles de motivar la incoación del procedimiento, la identificación de la persona o personas que pudieran resultar responsables y las circunstancias relevantes que concurran en unos y otros» (art. 55.2 de la Ley 39/2015). No obstante, esta fase ha de mantenerse en una mera comprobación liminar de los hechos, dado que el posible responsable no puede ejercer su defensa. En este sentido, J. A. Santamaría Pastor (2015), «Los Proyectos de ley del Procedimiento Administrativo Común de las Administraciones Públicas y de Régimen Jurídico del Sector Público: una primera evaluación", Documentación Administrativa, 2 (nueva época), enero-diciembre.

71 En este sentido Cano Campos (2016: 28), así como F. J. Bauzá Martorell (2015), «La denuncia en el Anteproyecto de ley de Procedimiento Administrativo Común de las Administraciones Públicas», Documentación Administrativa, 2 (nueva época).

72 Por supuesto, es perfectamente posible, y así ha sucedido en ocasiones, la incoación de un expediente como consecuencia de la orden de una Junta superior, en cuyo caso habrán de tenerse en cuenta los requisitos del art. 61 de la Ley 39/2015. 
estime oportunas. El acuerdo de incoación y la notificación deberán reunir los requisitos establecidos en el art. 64, que exige una calificación preliminar de los hechos y de las posibles sanciones, aunque excepcionalmente sigue aceptándose diferirla al pliego de cargos. Aunque la JEC ha asegurado siempre la debida separación entre instructor y órgano de resolución, no se excluye a aquel de intervenir en la deliberación y resolución del expediente ${ }^{73}$. A lo largo del procedimiento deberán respetarse las garantías de práctica de las pruebas necesarias para el esclarecimiento de los hechos, determinación de las responsabilidades que se deduzcan, contestación de la persona expedientada, formulación de propuesta de resolución y traslado al interesado para que presente las alegaciones para su defensa en el plazo correspondiente, requisitos todos ellos calificados de orden público, de manera que su omisión será constitutiva de nulidad de pleno derecho apreciable de oficio por la Junta correspondiente ${ }^{74}$.

En materia de prueba se permite al interesado solicitar cuantas considere necesarias para su defensa, que solo podrán rechazarse cuando sean manifiestamente improcedentes o innecesarias, mediante resolución motivada (art. 77.3). También en relación con la prueba es importante recordar que los hechos declarados probados por los órganos jurisdiccionales penales mediante resoluciones firmes vinculan «a las Administraciones Públicas respecto de los procedimientos sancionadores que substancien» (art. 77.4). En fin, dado que los presidentes de las Mesas tienen reconocida la condición de autoridad durante la jornada de votación (art. 91.1 LOREG), los hechos que hagan constatar en documento público — en este caso el acta de sesión, donde debe quedar reflejado todo incidente que afecte al orden en el colegio electoral, junto con los datos de quienes los hayan cometido (art. 94) - tienen valor probatorio iuris tantum, esto es, sin perjuicio de las pruebas que puedan aportar o señalar los sujetos expedientados (art. 77.5).

\section{RESOLUCIÓN}

La resolución dictada, que ha de ser motivada y congruente, y notificada debidamente al interesado dentro del plazo máximo para resolver so pena de caducidad del procedimiento $^{75}$, es recurrible ante la Junta de superior categoría, con la excepción obvia de las dictadas por la Junta Electoral Central (art.

AJEC de 11 de mayo de 1995.

AJEC de 17 de octubre de 1990.

75 Así se deduce del art. 25.1.b) de la Ley 39/2015, que no obsta, sin embargo, si la infracción no ha prescrito, para incoar nuevamente el expediente (art. 95). No obstante, dado que el plazo de prescripción que entendemos aplicable es coincidente con el 
21) y, en su caso, como veremos, ante la jurisdicción contencioso-administrativa, por el procedimiento ordinario, ya que no es de aplicación el contencioso-electoral ${ }^{76}$. Goza del privilegio de ejecutoriedad, puesto que, si se produjera el impago de las multas impuestas, la Junta Electoral correspondiente remitirá al órgano competente del Ministerio de Economía y Hacienda certificación del descubierto para su exacción por la vía de apremio, tal y como establece el art. 19.5 LOREG. Recientemente la Junta Electoral Central ha precisado que el órgano competente tanto para hacer el ingreso en período voluntario como para su exacción por vía de apremio es «la Dirección General del Tesoro y Política Financiera [actualmente Secretaría General del Tesoro y Política Financiera] o, en su defecto, la delegación provincial de la Agencia Provincial de la Administración Tributaria, para que procedan en el supuesto de falta de pago voluntario a hacer ejecutiva la sanción. En el caso de disolución de las Juntas electorales de zona o provinciales estas deberán comunicar esta circunstancia al órgano recaudatorio para que proceda a su requerimiento» ${ }^{77}$.

Creemos por lo demás que en el ámbito electoral está plenamente vigente el nuevo sistema de reconocimiento de responsabilidad con reducción de la cuantía de la sanción previsto en el art. 85 de la Ley 39/2015, ya que en todos los supuestos la sanción tiene únicamente carácter pecuniario. En tales casos, el pago voluntario por el presunto responsable, en cualquier momento anterior a la resolución, implica la terminación del procedimiento, salvo en lo relativo a la reposición de la situación alterada o a la determinación de la indemnización por los daños y perjuicios causados por la comisión de la infracción, con la consecuencia de que el órgano competente para resolver el procedimiento aplicará reducciones de, al menos, el $20 \%$ sobre el importe de la sanción propuesta. Dicha reducción debe estar determinada en la notificación de iniciación del procedimiento y su efectividad está condicionada al desistimiento o renuncia de cualquier acción o recurso en vía administrativa contra la sanción. Dado que el porcentaje de reducción puede ser incrementado reglamentariamente hay que entender que la Junta Electoral Central, mediante instrucción, podría ampliarlo, si bien lo escaso de los límites superiores de las sanciones no lo hace aconsejable.

máximo para resolver, en principio la caducidad implicará la imposibilidad de abrir un nuevo expediente.

76 STC $149 / 2000$.

77 AJEC 72/2012, de 10 de mayo. Por supuesto, la exacción en vía de apremio seguirá los trámites previstos en el Reglamento General de Recaudación, aprobado por Real Decreto 939/2005, de 29 de julio. 


\section{RECURSOS}

Podemos concluir esta parte general con una breve mención al régimen de recursos. Sin entrar en cuestiones generales que exceden de estas líneas, ha de recordarse que los recursos tanto administrativos como, sobre todo, jurisdiccionales contra las sanciones de las Juntas se rigen, en principio, por las disposiciones generales del derecho administrativo, toda vez que no entran dentro de la definición de acto electoral contenida en la STC 149/2000, de 1 de junio, con las especialidades a efectos de impugnación que esto conllevan. Ello se traduce en una mayor amplitud de plazos y formalismo en su tramitación.

Así, por lo que respecta al recurso ante la Junta superior previsto en el art. 21 LOREG, el plazo para resolver será de diez días en lugar de cinco, ya que la instrucción de un expediente sancionador, con su regulación actual, obligará con casi toda seguridad a que su resolución se produzca fuera de ese período electoral al que se refiere el art. 21.1 LOREG. En el caso del recurso contencioso-administrativo, este se va a regir por las normas generales contenidas en la Ley 29/1998, de 13 de julio, de la jurisdicción contencioso-administrativa, por lo que el recurrente podrá optar bien por los recursos generales, bien por el especial para la protección de derechos fundamentales. Entre los primeros, si la sanción ha sido impuesta por las Juntas de zona, y dado que el órgano competente para la resolución del recurso, los juzgados de lo contencioso-administrativo según dispone el art. 8.5, tiene carácter unipersonal y, conforme se ha visto, la cuantía de las sanciones en ningún caso se acercará siquiera a los 30000 euros que fija como tope el art. 78.1, será aplicable el procedimiento abreviado regulado en dicha norma. Para el resto de sanciones habrá de acudirse a los trámites del procedimiento ordinario, puesto que serán competentes órganos colegiados como las salas de lo Contencioso-Administrativo de los tribunales superiores de justicia o la Sala Tercera, de lo Contencioso-Administrativo, del Tribunal Supremo. Por supuesto, será relativamente sencillo invocar la concurrencia de la infracción de algunos de los derechos consagrados en el art. 25.1 CE para el derecho administrativo sancionador o en el art. 23.1 CE sobre participación política, para intentar justificar la pertinencia del procedimiento especial consagrado en los arts. 114 y siguientes de la Ley 29/1998 para la protección de los derechos fundamentales. No obstante, dado que las ventajas procesales no son tan evidentes - piénsese, por ejemplo, en el menguado efecto que se obtiene de la posibilidad de no agotar una vía administrativa previa que dura tan solo diez días- y que se corre un riesgo serio de inadmisión del recurso por inadecuación 
del procedimiento, en general se tiende a optar por los procedimientos generales $^{78}$.

En cuanto a los actos recurribles, en principio, y de acuerdo con el régimen general, podrán impugnarse los actos finalizadores del procedimiento y aquellos de trámite que resuelvan sobre el fondo o hagan imposible su continuación. Ello traducido al ámbito sancionador supone la posibilidad de interponer recurso contra la resolución sancionadora pero también contra la de no incoar un expediente con ocasión de denuncia. Sin embargo, también se han resuelto sobre el fondo recursos administrativos contra el propio acuerdo de incoación del expediente sancionador. En principio, y aunque en los supuestos encontrados ${ }^{79}$ la Junta Electoral Central ha desestimado el recurso y ha recordado la competencia de la Junta inferior, parece que hubiera resultado más correcta su inadmisión de plano, en la medida en que el acuerdo de incoación es un acto de trámite que no reúne los requisitos del art. 112.2 de la Ley 39/2015 para ser recurrible.

\section{CONSIDERACIONES SOBRE LAS DOS INFRACCIONES CON TIPIFICACIÓN ESPECÍFICA}

\section{LA VULNERACIÓN DEL RÉGIMEN SOBRE ENCUESTAS ELECTORALES}

Concluido el régimen general, y antes de referirnos a la potestad disciplinaria de la Administración electoral, procede examinar los dos únicos tipos sancionadores específicos que contempla la LOREG. El primero de ellos es la infracción de la normativa reguladora de las encuestas electorales ${ }^{80}$, que aparece en el art. 153.2, así como, para los supuestos constitutivos de delito

78 En este sentido, véase F. Pascua Mateo (2009), El control de las elecciones, Cizur Menor: Thomson-Civitas. Acerca de los problemas del procedimiento especial para la tutela de los derechos fundamentales véase F. Pascua Mateo (2011), «El procedimiento para la protección de los derechos fundamentales. Evolución y disfunciones bajo la Ley 29/1998", RAP, 185, págs. 113-162.

79 AJEC de 10 de mayo de 2011.

80 Normativa integrada principalmente en el ámbito estatal por el art. 69 LOREG, el art. 7 y la disposición adicional segunda de la Ley 39/1995, de 19 de diciembre, de organización del Centro de Investigaciones Sociológicas, los arts. 8 y 9 del Real Decreto 1214/1997, de 18 de julio, que establece la organización del Centro de Investigaciones Sociológicas, y la Instrucción 2/1993, de 26 de abril, de la Junta Electoral Central, de desarrollo del artículo 69.8 de la Ley Orgánica 5/1985, del Régimen Electoral General. 
electoral, en el art. 145. Como es sabido, el origen de esta infracción proviene de la Ley 14/1980, de 18 de abril, sobre Régimen de Encuestas Electorales, respecto de la que no se han producido variaciones sustanciales. Sin entrar en profundidad en el régimen sobre tales encuestas, que ha recibido atención suficiente por la doctrina ${ }^{81}$, sí procede recordar algunas consideraciones sobre la represión de las eventuales vulneraciones de sus normas.

Lo primero que procede es deslindar los ámbitos cubiertos por el delito tipificado en el art. 145 y la infracción administrativa del art. 153.2, para los que el criterio tradicional es el grado de culpabilidad del autor, de manera que constituyen delito las formas dolosas, mientras que serán mera infracción las puramente culposas ${ }^{82}$. Este criterio, con fundamento sólido en la redacción original de la LOREG, que se refería expresamente a «quienes dolosamente infrinjan la normativa», ha de mantenerse a pesar de que la exigencia de dolo ha desaparecido tras la reforma llevada a cabo por la LO $2 / 2011^{83}$, sin ninguna explicación sobre las razones que la motivan, más allá de la actualización de las penas asociadas al tipo de acuerdo con el esquema general del Código Penal. Y ello porque el art. 12 del Código Penal, norma aplicable al caso por la remisión que hace el art. 138 LOREG, exige que la comisión culposa de un delito esté expresamente prevista en el tipo concreto, circunstancia que, como es evidente, no concurre en el precepto mencionado. Sí podría en cambio plantearse si a raíz de la reforma es posible que la comisión dolosa de infracciones de menor entidad sea sancionable como infracción administrativa y no como delito ${ }^{84}$, circunstancia descartable en cambio con la redacción anterior. Lo cierto es que, aunque el principio de intervención mínima podría justificar tal propuesta, el art. 145 no establece ningún criterio que permita limitar su

81 Véase al respecto L. Gálvez Muñoz (2002), El régimen jurídico de la publicación de las encuestas electorales, Madrid: Congreso de los Diputados (con especial referencia al régimen sancionador en págs. 321 y ss.); asimismo, O. Sánchez Muñoz (2007), La igualdad de oportunidades en las competiciones electorales, Madrid: CEPC.

82 En este sentido, Gálvez Muñoz (2002: 323).

83 Ley Orgánica 2/2011, de 28 de enero. El nuevo texto es el siguiente: «Quienes infrinjan la normativa vigente en materia de encuestas electorales serán castigados con la pena de prisión de tres meses a un año, multa de doce a veinticuatro meses e inhabilitación especial para profesión, oficio, industria o comercio por tiempo de uno a tres años.»

84 En este sentido, J. J. Maza Martín (2015), «Artículo 145», en M. Delgado-Iribarren (dir.), Comentarios a la Ley Orgánica del Régimen Electoral General y a la Ley Orgánica de Referéndum, Madrid: La Ley, págs. 1262-1264 (pág. 1264), quien se refiere específicamente a la publicación de encuestas ciertas, pero con omisión de alguno de los datos exigidos por el art. 69.1 LOREG. 
tipificación a las infracciones más graves del régimen vigente y el art. 153 LOREG solo tipifica como infracción a aquellas que no constituyan delito. Se da, pues, un principio de preferencia de la norma penal ${ }^{85}$, que impide reducir al ámbito administrativo sancionador incluso los casos menores ${ }^{86}$, al menos desde un punto de vista teórico, puesto que el uso del art. 145 LOREG ha sido hasta el momento inédito.

En efecto, hasta la fecha no se ha producido ninguna condena penal por este delito, a pesar de que la Junta Electoral Central sí ha dado en alguna ocasión traslado a Fiscalía de conductas presuntamente infractoras ${ }^{87}$, y muy escasas sanciones administrativas. De estas la más conocida es la multa de 100000 pesetas impuesta a Prensa Española y al entonces director del diario $A B C$ por publicar en febrero de 1996 una supuesta encuesta del Centro de Investigaciones Sociológicas ${ }^{88}$. Sin entrar en los pormenores del asunto, que por lo demás planteó interesantes cuestiones procedimentales que hemos ya tratado, cabe preguntarse por qué no se estudió la posibilidad de remitir el asunto al Ministerio Fiscal con suspensión de la tramitación del expediente sancionador en tanto se obtuviera pronunciamiento al respecto, por si la conducta fuera constitutiva de delito, pues se hace difícil pensar en una comisión meramente culposa de la conducta típica ${ }^{89}$. Otra sanción que llegó a los tribunales fue la impuesta a Hermes Comunications, SA, editora del

85 Subrayado por C. Serena Velloso (1986), «Artículo 19», en L. Ma. Cazorla (dir.), Comentarios a la Ley Orgánica del Régimen Electoral General, Madrid: Civitas, págs. 181-186 (pág. 185).

86 Se mantiene así la postura que ya sostuvo J. L. Peñaranda Ramos (1986), «Artículo 145», en L. Ma. Cazorla (dir.), Comentarios a la Ley Orgánica del Régimen Electoral General, Madrid: Civitas, págs. 1196-1204 (pág. 1203).

87 Véanse AAJEC 137/1991, de 26 de mayo, por emisión en «Radio Intercontinental» de espacio de sondeo de intención voto para las elecciones locales en Madrid el día de la elección y 167/1991, de 26 de mayo, respecto de la publicación de encuestas por el diario Melilla Hoy.

88 AJEC de 27 de septiembre de 1996. El expediente sancionador se había incoado por AJEC de 17 de abril de 1996. Previamente la JEC, en acuerdos de 20 y 23 de febrero, había instado al diario en cuestión a rectificar la información ofrecida, aclarando que no se trataba de una encuesta en el sentido definido por el art. 69 LOREG. La suspensión cautelar de tales acuerdos fue rechazada por ATS, Sala de lo ContenciosoAdministrativo, Sección 7a, de 16 de diciembre de 1996.

89 STS, Sala de lo Contencioso-Administrativo, Sección 7a, de 22 de marzo de 1999. La propia Sala, por ATS, Sala de lo Contencioso-Administrativo, Sección 7a, de 27 de junio de 1997, había denegado la suspensión del AJEC resolutorio del expediente sancionador. 
diario El Punt ${ }^{90}$ por la publicación de una encuesta en el período de prohibición legal del art. 69.7 LOREG. El Tribunal Supremo rechazó la alegación de la recurrente que negaba el carácter de encuesta de la información publicada, a la que calificaba de mero sondeo interno, alegando que no cumplan o incluyan los requisitos de la llamada "ficha técnica», pues de estimarse este argumento podrían introducirse en la información al alcance de los electores sondeos carentes de fiabilidad pero aun así susceptibles de influir en las decisiones de los ciudadanos ${ }^{11}$.

Es destacable, por otra parte, el aumento llevado a cabo por la citada LO 2/2011 respecto de la cuantía de las multas, que pasan, como se ha señalado, a una horquilla de entre 3000 a 30000 euros, importes no demasiado elevados, pero que pueden atemperar las duras críticas vertidas por la doctrina y que compartimos, como hemos señalado anteriormente ${ }^{92}$.

Por último, cabe proponer de lege ferenda, como ya ha hecho algún autor $^{93}$, la previsión expresa de la posible autoría de este delito por parte de las personas jurídicas, pues, como es sabido, dada la redacción del art. 31 bis. 1 del Código Penal, la responsabilidad penal de estas solo es posible cuando así se disponga para cada delito concreto. En este caso, además de resultar muy sencilla la imputación del medio de comunicación que publica las encuestas sin atenerse a las disposiciones legales, dicha reforma permitiría unificar el régimen de responsabilidad administrativa — respecto de la que ninguna duda se plantea acerca de la imputabilidad de una persona jurídica - con el de la responsabilidad penal.

\section{LA SUPERACIÓN DE LA CUANTÍA MÁXIMA AUTORIZADA DE GASTOS ELECTORALES}

Se trata de una infracción con un régimen jurídico muy específico, puesto que su tipificación se lleva a cabo no en la propia LOREG, sino en la Ley Orgánica sobre Financiación de Partidos Políticos (LOFPP) ${ }^{94}$. A esta disposición remite el art. 153.3 LOREG, que, por otra parte, ha conocido una

90 La sanción consistió en una multa de 250000 pesetas. Véase AJEC de 21 de septiembre de 2000 .

91 STS, Sala de lo Contencioso-Administrativo, Sección 7a , de 30 de diciembre de 2002, fundamento primero.

92 Así, Gálvez Muñoz (2002: 330) se queja de lo inadecuado de las cantidades antes previstas por la modestia de su límite máximo (quinientas mil pesetas). Más duro es Sánchez Muñoz (2007: 325), que las califica de «simplemente ridículas».

93 En este sentido, Maza Martín (2015: 1264).

94 Ley Orgánica 8/2007, de 4 de julio, sobre financiación de los partidos políticos. 
existencia un tanto atormentada. En efecto, ausente de la versión original de la LOREG, fue introducido por la Ley Orgánica $1 / 2003^{95}$, que remitía la sanción de esta conducta a lo dispuesto «en el texto refundido de la Ley General Presupuestaria, aprobado por Real Decreto Legislativo 1091/1998, de 23 de septiembre [sic]». Más adelante la Ley Orgánica 2/2011 suprimió este párrafo, que ha vuelto a la LOREG de la mano de la Ley Orgánica $3 / 2015^{96}$, con el siguiente texto: «A las infracciones electorales consistentes en la superación por los partidos políticos de los límites de gastos electorales les será de aplicación lo previsto en la Ley Orgánica 8/2007, de 4 de julio, sobre financiación de los partidos políticos ${ }^{97}$.

La regulación de una potestad sancionadora específica en el ámbito de los gastos electorales no surge hasta 2012. En efecto, así aparece por primera vez tras la modificación de la LOFPP en dicha fecha ${ }^{98}$, cuyo art. 17 señalaba al respecto en su letra c) que: «Sin perjuicio de lo establecido en el artículo 134 de la Ley Orgánica 5/1985, de 19 de junio, del Régimen Electoral General, cuando el Tribunal de Cuentas advierta, en el ejercicio de su función, que los partidos políticos han superado los límites de gastos electorales previstos en dicha ley, impondrá una sanción equivalente al exceso producido». En la actualidad, tras la Ley Orgánica 3/2015 y el desarrollo del régimen sancionador que ha introducido en el ámbito de la LOFPP, la superación de los gastos electorales por los partidos políticos queda tipificada —caso único en el sistema sancionador electoral que, como hemos visto, carece en general de esta distinción- como infracción muy grave, grave o leve, según superen la cuantía máxima legal en, respectivamente, más de un $10 \%$, más de un $3 \%$ y menos del $10 \%$ y más de un 1 y hasta un $3 \%$ (art. 17, apartados 2 a 4). Las sanciones que pueden imponerse consisten en multa de entre el duplo y el quíntuplo del exceso, sin que en ningún caso puedan ser inferiores a 50000 euros, en el caso de infracciones muy graves, 25000 en el caso de graves y 5000 para las infracciones leves (art. 17 bis, apartados 1 a 3). La competencia

95 Ley Orgánica 1/2003, de 10 de marzo.

96 Ley Orgánica 3/2015, de 30 de marzo.

97 Acerca de la financiación electoral véase P. del Castillo Vera (1985), La financiación de partidos y candidatos en las democracias occidentales, Madrid: Centro de Investigaciones Sociológicas; y (1997), "La financiación de los partidos políticos: 1977-1997», Revista de las Cortes Generales, 41, págs. 153-167 (en especial págs. 160 y 161); R. L. Blanco Valdés (1995), «La problemática de la financiación de los partidos políticos en España: regulación jurídica y propuestas de reforma», Revista de Estudios Políticos, 87, págs. 163-197; M. A. Presno Linera (1999), «La reforma del sistema de financiación de los partidos políticos», REDC, 57, págs. 205-228, y Sánchez Muñoz (2007: 177 y ss.).

Llevada a cabo por medio de la Ley Orgánica 5/2012, de 22 de octubre. 
sancionadora se atribuye al Tribunal de Cuentas, sin perjuicio además de la función fiscalizadora que le otorga el art. 134 LOREG. El procedimiento administrativo sancionador está regulado en el art. 18, que dispone su incoación por el Pleno del Tribunal tras un trámite de informaciones previas con audiencia al partido político interesado. A continuación, y tras el nombramiento de instructor, se remite al partido expedientado el acuerdo de incoación con toda la documentación y pruebas disponibles para formulación de unas primeras alegaciones. Está prevista además la apertura de un trámite de prueba si así lo solicita el partido o lo considera oportuno el instructor y la formulación de una propuesta de resolución con propuesta de archivo o, en su caso, de la sanción que deba imponerse, de la que se da traslado al partido expedientado para alegaciones. La resolución corresponde al Pleno.

Respecto de esta normativa procede apuntar algunas observaciones. Por de pronto es sumamente defectuosa la técnica de la regulación en la LOFPP, que en buena medida sortea la reserva de ley orgánica electoral deducida por el Tribunal Constitucional a partir de los arts. 70, 81 y $86 \mathrm{CE}$, a pesar de la remisión expresa del art. 153.3 LOREG. Y ello no solo por una cuestión de teoría de fuentes del derecho, sino también porque, como consecuencia de ello, existe una importante laguna, ya que las conductas tipificadas como infracción recaen solo sobre los partidos políticos, aun cuando pueden ser cometidas por otras formaciones susceptibles de presentar candidaturas electorales, como son las federaciones, coaliciones y agrupaciones (art. 43.1 LOREG). Es cierto que las federaciones podrían entenderse incluidas, puesto que son sujetos que trascienden el mero proceso electoral y se inscriben en el Registro de Partidos Políticos del Ministerio del Interior (art. 1.3 de la Ley Orgánica 6/2002, de 27 de junio, de Partidos Políticos y art. 44.1.a) LOREG). Pero indudablemente queda fuera del tipo sancionador el supuesto de las agrupaciones de electores e incluso el de las coaliciones electorales, que, a pesar de estar integradas por partidos, son formaciones a efectos puramente electorales y han de constituirse necesariamente al inicio de cada proceso (art. 45 LOREG). La ley consolida así, por una defectuosa técnica, una desigualdad no justificable entre candidaturas que afecta, además, a un tema sumamente sensible como es la financiación de las elecciones. Ocioso es, por lo demás, recordar que el intérprete no podrá subsanar esta desigualdad de regímenes, dado que en el derecho sancionador no cabe la analogía ni tan siquiera la interpretación extensiva, por lo que sólo una reforma legal podrá en el futuro corregir esta situación.

Una segunda consideración es la atribución competencial al Tribunal de Cuentas. Es cierto que el Tribunal goza de un conocimiento y una experiencia en el control del gasto del que carecen las Juntas Electorales, incluida la Central. Por ello su intervención en el procedimiento administrativo ha de ser intensa. Pero no lo es menos que ello no implica que haya de ser el órgano 
titular de la potestad sancionadora, rompiendo así con la exclusividad que la legislación otorga a la Administración electoral en cuanto a la titularidad de la potestad sancionadora en materia electoral, bien justificada por el cuidado puesto en su independencia por razón del modo de designación de sus miembros. El Tribunal de Cuentas podría haber conservado sus clásicas funciones fiscalizadoras, con la consecuencia natural de la reducción de la subvención de los gastos electorales en el caso de que se haya superado el máximo legal, añadiéndole la condición de órgano denunciante para la incoación del expediente sancionador correspondiente por parte de la Junta Electoral Central, acompańando a la denuncia de un informe y los antecedentes necesarios para pronunciarse. Este sistema, más respetuoso con la organización institucional general de la Administración electoral y con la propia naturaleza jurídica del propio Tribunal de Cuentas99, y más coherente con la propia LOREG, que en su art. 132.4 sigue atribuyendo a las Juntas electorales la potestad sancionadora sobre la contabilidad electoral, se sigue con éxito en otros países. Es el caso de Francia, donde existe un órgano especializado que examina las cuentas, la Comision Nationale des Comptes de Campagne et des Financements Politiques $(\mathrm{CNCCFP})^{100}$, que en el caso de encontrar una irregularidad remite el asunto al Consejo Constitucional para que instruya el procedimiento oportuno.

Por último, aunque es verdad que se han reforzado notablemente las sanciones que pueden imponerse, nuestro sistema sigue siendo bastante benigno en comparación con nuestros vecinos. En efecto, la única sanción aplicable, como en el resto de los casos, es la de multa. Es cierto que su cuantía es potencialmente la más alta de las disponibles para la Administración electoral, ya que es la única tipificada en proporción a la gravedad de la infracción y de las pocas con un suelo mínimo. Además es compatible con la facultad fiscaliza-

99 Recuérdese que el Tribunal de Cuentas divide sus funciones entre una función de fiscalización y una jurisdicción contable, que persigue determinar la responsabilidad, a efectos del reintegro de las cantidades correspondientes, y respecto de la cual se le reconoce la condición de órgano jurisdiccional (STC 215/2000, de 18 de septiembre). La titularidad de una potestad sancionadora como la referida no casa bien con ninguna de las dos actividades.

100 Creada por la Loi no 90-55, du 15 janvier 1990 relative à la limitation des dépenses électorales et à la clarification du financement des activités politiques. Ha sido calificada por el Consejo Constitucional como "autorité administrative et non une juridiction» (décision 91-1141 du 31 juillet 1991). Por su parte, el Consejo de Estado, en su memoria [rapport public] de 2001 clasificó a la Comisión dentro de las autoridades administrativas independientes, estatuto jurídicamente consagrado en la Ordonnance $n^{\circ}$ 2003-1165 du 8 décembre 2003 portant simplifications administratives en matière électorale. 
dora del Tribunal que le permite proponer una reducción en las subvenciones electorales en todo lo que sobrepase el límite total de gasto. Sin embargo, en otros países, como el caso francés citado, llega a imponerse la pérdida del escaño y la declaración como inelegible del candidato sancionado, amén del pago de una multa equivalente al exceso de gasto e incluso el ingreso en prisión, normativa que ha recibido el espaldarazo del $\mathrm{TEDH}^{101}$. En línea similar puede situarse al Reino Unido, que para las formas más graves — falta de declaración de gastos electorales por el agente electoral (return) — prevé la pérdida del escaño ${ }^{102}$, e incluso Italia que, de manera más renuente que los anteriores, prevé también la privación del escaño y la inelegibilidad ${ }^{103}$. Bien es verdad que en Espańa, con un sistema de circunscripciones plurinominales, la pérdida de la elección por parte de todos los candidatos en una circunscripción resulta a todas luces excesiva ${ }^{104}$, a la par que las responsabilidades individuales quedan atenuadas, pero para los casos más graves y los reincidentes tal vez debieran considerarse alternativas como las antes apuntadas, a las que pudiera añadirse la inelegibilidad para los siguientes comicios equivalentes ${ }^{105}$.

101 Actuales arts. L-52.11 y siguientes del Code des Élections. La STEDH es la Pierre Bloch c. Francia, de 21 de octubre de 1997. Un comentario al respecto puede consultarse en L. Martín-Retortillo Baquer (2010), «Los derechos electorales a la luz de la jurisprudencia del Tribunal Europeo de Derechos Humanos», en F. Pascua (dir.), Estado democrático y elecciones libres: Cuestiones Fundamentales de Derecho Electoral, Cizur Menor: Civitas Thomson-Reuters, págs. 17-114.

102 Artículo 159, en relación con los arts. 81, 82 y 84 de la Representation of the People Act 1983. Hasta el 16 de febrero de 2001 el apartado 2 preveía además la declaración de inelegibilidad para concurrir a la misma circunscripción durante diez años. Sin embargo, este párrafo ha sido derogado por la Political Parties, Elections and Referendums Act 2000.

103 En este caso no son los jueces, sino la Cámara respectiva la que acuerda la sanción - con la consiguiente introducción de criterios políticos, matizada eso sí por la iniciativa atribuida al Colegio Regional de Garantía Electoral, compuesto mayoritariamente por jueces_ - y las sanciones citadas se reservan para supuestos como la superación de los gastos en más del doble del límite (art. 15, apartados 9 y 10 de la Legge 10 dicembre 1993, n. 515 - Disciplina delle campagne elettorali per l'elezione alla Camera dei deputati e al Senato della Repubblica).

${ }^{104}$ Consideraciones similares ha expuesto P. Lucas Murillo de la Cueva (1993), «La financiación de los partidos políticos. Ponencia base de un debate», Anuario de Derecho constitucional y parlamentario, 5, págs. 107-131.

105 Mayor dureza aún reclama B. Cid Villagrasa (2010), «La financiación electoral», en F. Pascua (dir.), Estado democrático y elecciones libres: Cuestiones Fundamentales de Derecho Electoral, Cizur Menor: Civitas Thomson-Reuters, págs. 543-583. Más templado, si bien aboga también por un endurecimiento de las sanciones, Sánchez Muñoz (2007: 196). 


\section{LA POTESTAD DISCIPLINARIA}

Una última cuestión que procede tratar es el ejercicio de las competencias disciplinarias ${ }^{106}$ que ostentan las Juntas electorales en razón del art. 19.1.j), que atribuye a la Central la de: «Ejercer potestad disciplinaria sobre todas las personas que intervengan con carácter oficial en las operaciones electorales». $\mathrm{El}$ art. 19.2 reproduce esta misma competencia para las Juntas provinciales y de zona. Con esfuerzo podemos llegar a considerar, y esta es una operación con más implicaciones de las que parece, que el art. 153 proporciona una tipificación de faltas — por supuesto con todos los defectos ya señalados en el ámbito sancionador-y de las sanciones, en este caso con el fundamento que proporciona la distinción de cuantías entre autoridades y funcionarios y quienes no lo son, y que oscilan para aquellos entre trescientos y tres mil euros. Y ya está.

El laconismo de la LOREG, que genera no pocas dificultades, seguramente pueda explicarse por una cierta irreflexión del legislador, que incorporó por inercia histórica una competencia que ostentaban las Juntas electorales desde su nacimiento. Ahora bien, si en las leyes de 1890 y 1907 la presencia de esta facultad estaba plenamente justificada y acotada ${ }^{107}$, puesto que se limitaba esencialmente a las operaciones de formación y mantenimiento del censo electoral, cuya confección se ponía en manos de las Juntas, y contaba además, como hemos visto al principio, con una somera tipificación de faltas y sanciones, resulta ya más discutible su mantenimiento en el Real Decreto Ley 20/1977, que la extiende además a todas las operaciones electorales (art. 14.6) a la vez que suprime las referencias a los tipos infractores. En el caso de la LOREG, una vez que la elaboración material del censo pasa a la Oficina del Censo Electoral, bien pudiera haberse prescindido de cualquier referencia disciplinaria, difícilmente explicable en principio en una Administración de funcionamiento intermitente como la electoral, salvo para otorgar a las Juntas una función de denuncia y de toma de

106 Sobre la potestad disciplinaria puede consultarse, entre otros, B. Marina Jalvo (2001), El régimen disciplinario de los funcionarios públicos, Valladolid: Lex Nova; T. Quintana López (2009), «La potestad disciplinaria de las Administraciones sobre los empleados públicos», Documentación Administrativa, 282-283, tomo II, en especial, págs. 361-412; J. M. Trayter Jiménez (2008), «El régimen disciplinario de los funcionarios públicos en el EBEP», en S. del Rey Guanter (dir.), Comentarios al Estatuto Básico del Empleado Público, Madrid: La Ley/Wolters Kluwer, págs. 901-932.

107 La atribución a las Juntas Electorales de la potestad de «ejercer jurisdicción disciplinaria sobre las personas que intervengan con carácter profesional» en las operaciones relativas al censo electoral se contemplaba en el art. 18.5 de la Ley de 1890 y el art. 15.7 de la Ley de 1907. 
razón de las actuaciones conducidas por las Administraciones de adscripción de los empleados públicos implicados.

Todo ello seguramente ha llevado a la Junta Electoral Central a asumir una posición un tanto dubitativa con el ejercicio de esta potestad. Así, en $1988^{108}$ proclamó con énfasis que las competencias disciplinarias correspondían a las Juntas electorales y que la Administración de origen debía abstenerse de cualquier otra actuación que no fuese la de poner en conocimiento de estas los hechos acaecidos a fin de que iniciaran los trámites oportunos ${ }^{109}$, postura mantenida en 1994, cuando declaró además que sus propias competencias podían delegarse en las Juntas provinciales o de comunidad autónoma, según el ámbito territorial de las elecciones ${ }^{110}$. Más tarde pueden encontrarse, por el contrario, ejemplos en los que se acepta que sea otra Administración, en concreto la de origen de los propios empleados públicos, la que incoe el expediente disciplinario correspondiente ${ }^{111}$. Sin embargo, en los últimos tiempos vuelve a detectarse un giro en su criterio, de manera que se ha llegado a remitir a una Junta inferior algún asunto con la instrucción de que se incoe el expediente correspondiente ${ }^{112}$. Dicho giro no ha estado

108 Con anterioridad a la LOREG, el AJEC 178/1979, de 24 de septiembre, acordó incoar "expediente disciplinario" a distintos partidos políticos por falta de presentación de la contabilidad electoral ante las Juntas. A pesar del tenor literal parece más bien tratarse de un expediente sancionador.

109 Se trata, recordemos, de los AAJEC de 16 de septiembre y 21 de octubre de 1988. En este sentido véase E. Arnaldo Alcubilla (2009), «Infracciones electorales», en E. Arnaldo y M. Delgado-Iribarren (coords.), Diccionario electoral, Madrid: Wolters Kluwer España, págs. 269-271.

110 AJEC de 27 de febrero de 1990.

111 Por ejemplo, el AJEC 272/1989, de 22 de noviembre, dio por buenas las actuaciones del director general de RTVE que comunicaba que se había incoado expediente disciplinario por falta muy grave tipificada en el correspondiente convenio colectivo, limitándose la Junta a reclamar que se le informara del resultado.

112 Es el caso del AJEC 314/1996, de 30 de abril, en el que se resuelve: "Incoar expediente disciplinario al funcionario de Correos D. C. P. P. por presunto incumplimiento de las normas obligatorias sobre entrega de la documentación para el voto por correo, encomendando su tramitación a la Junta Electoral Provincial de Barcelona». Asimismo, el AJEC 161/2016, de 15 de junio, recuerda a la Junta Electoral Provincial de La Rioja que si «sospecha de manera fundada que se han producido o se están produciendo irregularidades en las solicitudes de voto por correo correspondientes a otros electores, debe adoptar cuantas medidas estime pertinentes para corregir dichas irregularidades antes de que sean irremediables, así como acordar las medidas disciplinarias que, en su caso, procedan». 
exento en cualquier caso de otros tantos titubeos ${ }^{113}$ que impiden deducir una doctrina asentada.

Aceptada, no obstante, y como no puede ser de otra manera, la vigencia de esta potestad, lo primero que ha de apuntarse es que tan escasa referencia suscita importantes dudas sobre el régimen aplicable. Para resolverlas convenientemente procede, no obstante, apuntar una interpretación general de esta potestad disciplinaria, inédita y quizá sorprendentemente novedosa tras más de treinta ańos de vigencia de la LOREG, pero que permite reconducir a términos aceptables la regulación vigente y solventar las dudas que es evidente que han asaltado a la Junta Central hasta el momento. En realidad, la propuesta es sencilla: hasta el momento la atribución de potestades disciplinarias se ha considerado como una competencia en régimen de exclusividad, de forma que o correspondía a las Juntas o a la Administración de origen, en su caso, del empleado infractor. Sin embargo, es evidente que esto no tiene por qué ser así. El tenor literal del art. 19.2.j) es meramente atributivo de competencias, «ejercer jurisdicción disciplinaria», pero ello no impide que la Administración u organismo al que esté vinculado el empleado pueda, conforme a sus propias normas ${ }^{114}$, adoptar las medidas disciplinarias que estime oportunas.

113 En el AJEC 59/2016, de 13 de abril, al haber recibido informe de la Subsecretaría de Asuntos Exteriores y de Cooperación relativo a unas actuaciones informativas previas a la incoación de expediente sancionador ante una incidencia ocurrida en la Embajada de España en Helsinki con el voto CERA, no se fue más allá de tomar nota «de los procedimientos disciplinarios iniciados, acordes con la gravedad de las infracciones cometidas». Más llamativo aún es el AJEC 338/2015, de 8 de junio, en el que, con relación a un informe sobre el extravío de un despacho electoral conteniendo votos por correo, se da traslado a la Dirección General de Política Interior para su remisión al Ministerio de Fomento a efectos de que adopte las medidas que conforme al ordenamiento vigente considere oportunas en relación a los hechos descritos y se requiere de Correos que comunique a la JEC «las decisiones disciplinarias o de otra índole que haya podido adoptar respecto a los responsables de los hechos recogidos en este Informe».

${ }^{114}$ Entre ellas deben señalarse el Texto Refundido del Estatuto Básico del Empleado Público (EBEP), aprobado por Real Decreto Legislativo 5/2015, de 30 de octubre. Sus arts. 93 y ss. establecen los principios del régimen disciplinario de los empleados públicos, las líneas de su procedimiento y tipifican las infracciones muy graves aplicables tanto al personal funcionario como al laboral y que contempla tipos que, como se verá, bien pudieran aplicarse al caso. Esta norma ha de completarse, para los funcionarios, con el Reglamento de Régimen Disciplinario de los Funcionarios de la Administración del Estado, aprobado por el Real Decreto 33/1986, de 10 de enero. Para el personal laboral rige la tipificación de infracciones contenidas en los convenios 
El único obstáculo real para tal interpretación es la posible vulneración de la prohibición del bis in idem. Ahora bien, como establece el art. 31.1 de la Ley 40/2015, que resulta, como hemos visto, de aplicación supletoria, incluido el ámbito disciplinario, para que dicha prohibición opere es necesario «que se aprecie identidad del sujeto, hecho y fundamento». Y también es claro que el bien jurídico protegido varía en uno y otro caso: la Administración electoral persigue exclusivamente garantizar «la transparencia y objetividad del proceso electoral y del principio de igualdad» (art. 8.1 LOREG), mientras que la Administración de origen tendrá interés en asegurar el cumplimiento de sus deberes por parte de sus empleados. Así, el tipo sancionador más extendido, la «violación de la imparcialidad, utilizando las facultades atribuidas para influir en procesos electorales de cualquier naturaleza y ámbito", previsto en el art. 95.2.h) del EBEP, trata de hacer efectivo el deber de imparcialidad consagrado en el art. 53, que proscribe cualquier actuación o posición personal que comprometa el principio de objetividad y neutralidad en el ejercicio de sus funciones y del servicio público y menos aún entrañe discriminación a los ciudadanos basada en sus convicciones (apartados 2, 4 y 11). Como es sabido,

colectivos, a los que remite el art. 94.2.a) del EBEP. En contra se ha manifestado Cano Campos (2016: 45). No podemos compartir este criterio dado que la Ley 40/2015 no resulta de aplicación especial en la materia frente a un EBEP cuyo Texto Refundido se aprobó incluso con posterioridad a aquella y que es taxativo en su remisión al convenio. Con incidencia en el ámbito electoral podemos citar sin ánimo de exhaustividad algunos convenios que regulan una infracción muy grave y muy similar a la transcrita en el texto para los funcionarios públicos. Se trata del III Convenio colectivo único para el personal laboral de la Administración General del Estado, registrado y publicado por Resolución de la Dirección General de Trabajo de 3 de noviembre de 2009 (art. 78.2.c).10). Asimismo, del Acuerdo de 3 de diciembre de 2007, de la Mesa General de Negociación de la Administración General del Estado sobre condiciones de trabajo del personal laboral en el exterior, aprobado por el Consejo de Ministros con fecha 25 de enero de 2008 (apartado 15.1.h). El procedimiento y las sanciones se regulan en el Acuerdo de la Mesa General de Negociación de la Administración General del Estado de 9 de junio de 2011, sobre el procedimiento de régimen disciplinario del personal laboral de la Administración General del Estado en el exterior. También merece mención el III Convenio colectivo de la Sociedad Estatal Correos y Telégrafos, SA, registrado y publicado por Resolución de la Dirección General de Trabajo de 10 de junio de 2011. Curiosamente su régimen sancionador, de especial relevancia por la incidencia del voto por correo en el proceso electoral, no contempla dicha infracción, aunque los comportamientos que lo obstaculicen pueden tener fácil encaje en varios de los tipos de los arts. 83 a 85 y, en especial, para las de mayor entidad, en la falta muy grave de detención arbitraria, intencionado curso anormal, sustracción, ocultación o infidelidad en la custodia de la correspondencia postal prevista en el art. 85.a). 
los principios éticos referidos «informarán la interpretación y aplicación del régimen disciplinario de los empleados públicos» (art. 52), por lo que es sencillo justificar, con disposiciones legales específicas, la diferencia de fundamento punitivo en uno u otro caso. En consecuencia, el régimen correspondiente a las faltas disciplinarias permite a las Juntas electorales imponer sanciones consistentes exclusivamente en multas en las cantidades tasadas por el art. 153, que en estos términos expuestos pueden considerarse, frente a lo que hemos señalado para el ámbito sancionador, más que suficientes, y compatibles con las sanciones que, como consecuencia de su normativa disciplinaria específica, puedan imponerse por las Administraciones con las que mantengan su relación de servicio los empleados infractores.

A partir de esta premisa las cuestiones más debatidas encuentran una solución relativamente simple. Por de pronto es preciso determinar quiénes son los sujetos sobre los que procede el ejercicio de dicha potestad disciplinaria. Es evidente que el carácter oficial de la intervención requiere de una relación formalizada con la Administración electoral o las unidades administrativas que, como Correos, las fuerzas y cuerpos de seguridad o las oficinas consulares, desarrollan tareas auxiliares durante las elecciones. En este sentido, dos son las posturas que se han defendido. Por una parte, quienes sostienen ${ }^{115}$ el recurso a la definición de funcionario que a efectos de los preceptos sobre delitos e infracciones electorales se proporciona en el art. 135 LOREG. Dice su primer párrafo que «son funcionarios públicos los que tengan esta consideración según el Código Penal, quienes desempeñen alguna función pública relacionada con las elecciones, y en particular los Presidentes y Vocales de las Juntas Electorales, los Presidentes, Vocales e Interventores de las Mesas Electorales y los correspondientes suplentes». De conformidad con el art. 24.2 del Código Penal: «Se considerará funcionario público todo el que por disposición inmediata de la Ley o por elección o por nombramiento de autoridad competente participe en el ejercicio de funciones públicas». Esta postura encuentra un sólido anclaje tanto en el derecho histórico expuesto como en la interpretación sistemática de la LOREG, puesto que si el art. 153 no solo recoge los tipos de infracciones y las sanciones ad extra, sino también las disciplinarias, no puede obviarse el hecho de que el art. 135 se encuentra dentro de las disposiciones comunes del título en el que aquel se encuadra. Es además indiscutible su extensión a los miembros de las Juntas, puesto que el art. 16.2 LOREG faculta a «la Junta superior» para suspenderlos en sus funciones «mediante el acuerdo de la mayoría absoluta de sus componentes» por expediente por delitos o faltas electorales.

115 Tempranamente, Serena Belloso (1986: 184). 
Por el contrario, se ha apuntado también una concepción estricta de los sujetos afectados ${ }^{116}$, limitando la potestad disciplinaria a quienes ostenten la condición de funcionarios o empleados públicos y dejando el resto, en su caso, para el régimen sancionador, lo que excluiría a los miembros de las mesas e interventores. Seguramente la razón que la justifica es la consideración de que, en ausencia de una normativa reguladora del régimen disciplinario específico en el derecho electoral, no es posible aplicar disposiciones previstas para empleados públicos a quienes no lo son. Sin embargo, con la construcción propuesta no existe mayor dificultad, puesto que para los miembros de mesas e interventores serán de aplicación exclusivamente las sanciones electorales del art. 153, eso sí, las correspondientes a los funcionarios en el sentido expuesto de la LOREG.

El otro tema relevante es la normativa que ha de considerarse. En este caso, despejados los efectos puramente electorales de la potestad disciplinaria de las Juntas, la cuestión se reduce a determinar cuál es la normativa que ha de aplicarse supletoriamente, tanto respecto de los principios que informan esta potestad como respecto del procedimiento que ha de seguir el expediente. En principio parecería sencillo inclinarse por la normativa de carácter disciplinario, en particular el EBEP, y su desarrollo por el Reglamento de 1986, a pesar de algunas dudas jurisprudenciales que ha generado su rango normativo para la tipificación de infracciones graves y leves ${ }^{117}$, irrelevantes en el ámbito electoral, y que podría disciplinar el procedimiento para tramitar el expediente. Dada la condición funcionarial, a efectos de la LOREG, de todos los empleados públicos no sería necesario acudir a ninguna otra disposición. Ahora bien, lo cierto es que la remisión normativa del art. 120 LOREG es a la ley de procedimiento administrativo, opción que tendría la ventaja de unificar las disposiciones aplicables a la potestad sancionadora con la disciplinaria y

116 Delgado-Iribarren García-Campero (2015: 228).

117 Así el TSJ de Valencia (Sentencias de 28 de julio de 2010, de 3 de diciembre de 2014 y de 16 de enero de 2015, entre otras) considera derogado dicho reglamento por el EBEP y carentes de cobertura legal sus infracciones graves y leves. De inquietante ha calificado esta jurisprudencia Sánchez M. Morón (2013), Derecho de la función pública, Madrid: Tecnos (pág. 319). Por el contrario, la Audiencia Nacional ha expresado reiteradamente que, a tenor del art. 95.2 EBEP, el Reglamento de 1986 ha de considerarse en vigor hasta que se apruebe la correspondiente ley de la función pública estatal. Es el caso de la SAN, Sala de lo Contencioso-Administrativo, Sección 4a , de 26 de marzo de 2014, fundamento cuarto, que reproduce la jurisprudencia ya expuesta en distintas resoluciones de esa misma sala (Sección 5a) de 30 de mayo de 2011 (rec. 244/2010) y 8 de febrero de 2012 (rec. 163/2011), y 4 de diciembre de 2013 (Sección 4 a apel. 78/2013), entre otras. Acerca de esta cuestión véase Casino Rubio (2015). 
que podría serle útil a las Juntas. De hecho este es el criterio que ha adoptado durante mucho tiempo la Junta Electoral Central, que ignoró la legislación disciplinaria en favor del Código Penal como normativa supletoria cuando la Ley de Procedimiento de 1958 no contemplaba los principios reguladores de la potestad sancionadora y se limitaba a regular los trámites del expediente ${ }^{118}$ y, más tarde, remitió expresamente a la Ley 30/1992 para instruir expedientes disciplinarios ${ }^{119}$ incluso a pesar de la previsión del art. 127.3 acerca de su no extensión a estos supuestos. En cualquier caso, en la actualidad no hay demasiadas consecuencias derivadas de la opción por uno u otro texto, salvo quizá respecto del procedimiento, debido a las novedades de la Ley 39/2015, dada la convergencia entre la legislación sancionadora y la disciplinaria, acentuada recientemente con la entrada en vigor de la Ley 40/2015, que, al contrario que su predecesora, los declara extensibles «al ejercicio por las Administraciones Públicas de su potestad disciplinaria respecto del personal a su servicio, cualquiera que sea la naturaleza jurídica de la relación de empleo» (art. 25.3) ${ }^{120}$.

118 Incluso con posterioridad a la aprobación de la Ley 30/1992, por su efecto favorable al potencial expedientado, un funcionario de Correos, puesto que se le aplicó el plazo de prescripción de dos meses previsto para las faltas, en lugar del de seis meses que cuanto menos hubiera debido aplicarse. La JEC, con buen criterio, mantuvo la regulación vigente en el momento de producirse los hechos sancionables. Véase AJEC 15/1994, de 18 de enero. Con anterioridad se había sostenido esta aplicación supletoria por Cosculluela Montaner y Muñoz Machado (1978: 90).

119 AJEC 314/1996, de 30 de abril.

${ }^{120}$ Novedad criticada por el Consejo de Estado en su dictamen 275/2015, pág. 39, por su falta de motivación. En cambio, la doctrina se muestra en general favorable. Es el caso de Cano Campos (2016) y de Burzaco Samper (2016: 107). 
